UNIVERSIDADE DE SÃO PAULO

DAYANA FERRARI HADDAD

\begin{abstract}
VIVÊNCIAS DE PERDA E LUTO DE IDOSOS RESIDENTES EM UMA INSTITUIÇÃO ASILAR DE LONGA PERMANÊNCIA EM RIBEIRÃO PRETO-SP
\end{abstract}

RIBEIRÃO PRETO

2008 


\title{
VIVÊNCIAS DE PERDA E LUTO DE IDOSOS RESIDENTES EM UMA INSTITUIÇÃO ASILAR DE LONGA PERMANÊNCIA EM RIBEIRÃO PRETO-SP
}

\author{
Dissertação apresentada à \\ Escola de Enfermagem de Ribeirão Preto da \\ Universidade de São Paulo para \\ obtenção do título de \\ Mestre em Enfermagem Psiquiátrica.
}

Área de concentração: Enfermagem Psiquiátrica Linha de pesquisa: Promoção de Saúde Mental Orientadora: Profa. Dra. Renata Curi Labate 
AUTORIZO A REPRODUÇÃO E DIVULGAÇÃO TOTAL OU PARCIAL DESTE TRABALHO, POR QUALQUER MEIO CONVENCIONAL OU ELETRÔNICO, PARA FINS DE ESTUDO E PESQUISA, DESDE QUE CITADA A FONTE.

Haddad, Dayana Ferrari.

Vivências de perda e luto de idosos residentes em uma instituição asilar de longa permanência em Ribeirão Preto-SP. Ribeirão Preto, 2008.

64 p.: il.; $30 \mathrm{~cm}$

Dissertação apresentada à Escola de Enfermagem de Ribeirão Preto/USP. Área de Concentração: Enfermagem Psiquiátrica.

Orientadora: Labate, Renata Curi.

1. Idoso. 2. Institucionalização. 3. Luto. 


\section{FOLHA DE APROVAÇÃO}

\section{DAYANA FERRARI HADDAD}

VIVÊNCIAS DE PERDA E LUTO DE IDOSOS

RESIDENTES EM UMA INSTITUIÇÃO ASILAR DE

LONGA PERMANÊNCIA EM RIBEIRÃO PRETO-SP

Dissertação apresentada à Escola de Enfermagem de

Ribeirão Preto da Universidade de São Paulo para obtenção do título de Mestre em Enfermagem Psiquiátrica.

Área de concentração: Enfermagem Psiquiátrica

Linha de pesquisa: Promoção de Saúde Mental

\section{APROVADO EM:}

\section{BANCA EXAMINADORA}

Prof. Dr.:

Instituição:

Assinatura:

Prof. Dr.:

Instituição:

Assinatura:

Prof. Dr.:

Instituição:

Assinatura:

Prof. Dr.:

Instituição:

Assinatura:

Prof. Dr.:

Instituição:

Assinatura: 


\section{DEDICATÓRIA}

Dedico este trabalho aos idosos do Lar Padre Euclides, verdadeiros exemplos de humildade e coragem, pela sua força e vontade de viver, sem os quais esta realização não teria sido possível. 


\section{AGRADECIMENTOS}

Gostaria de agradecer, primeiramente, à minha orientadora fiel, Profa. Dra. Renata Curi Labate, pelo voto de confiança, pelo ombro amigo nas horas difíceis, pelos valiosos encontros, pela ajuda "virtual" $e$, primariamente, pela amizade e pelas palavras acolhedoras que não me deixaram desistir e fizeram-me amadurecer e reconhecer o profissional e ser humano que quero ser.

À minha família, em especial ao meu pai Emílio (in memoriam), à minha mãe Sirley e minha tia Ivete, meus mestres primeiros, pela dedicação integral e exclusiva e por terem me ensinado o verdadeiro valor da educação.

Ao meu noivo, Evandro, pela ajuda incondicional, mesmo sem permanecer o tempo todo ao meu lado, mas o fazendo em pensamento, sempre com demonstrações de carinho, afeto, amor e companheirismo.

Aos meus futuros sogros e cunhado, Guida, Evandro e Gustavo, pelos "puxões de orelha", essenciais ao reconhecimento da importância deste trabalho e ao desejo de seguir em frente.

À minha futura cunhada, Thania, e seu marido Glenn, pelo carinho e imensa ajuda com o inglês.

À Mirna, amiga desde sempre, por ter-me acompanhado em minha primeira vez na USP-RP e, simplesmente, por ser minha amiga. 
À Dri Bosco, companheira de mestrado, de orientação e de incansáveis viagens a Campinas.

À Thaís, minha mais nova amiga de faculdade, que me deu força para continuar a caminhada, independente do caminho.

Ao Dr. Colin Murray Parkes, pela atenção nos Congressos, pelos escritos incomparáveis e pelo conhecimento imensurável que me tem proporcionado.

À Profa. Dra. Toyoko Saeki, coordenadora do Programa de Mestrado em Enfermagem Psiquiátrica, pela compreensão e apoio.

À Profa. Dra. Sueli Marques pela participação na banca do meu exame de qualificação, pelas sugestões bibliográficas, pelas contribuições imprescindiveis e pela compreensão, acima de tudo.

À Profa. Dra. Elizabeth Ranier Martins do Valle, pela participação na banca do meu exame de qualificação e pelas magníficas sugestões.

À Profa. Dra. Antonia Regina Ferreira Furegato, pela sinceridade e contribuição científica.

À Profa. Dra. Sônia Maria Villela Bueno, pelas palavras amigas e fortalecedoras.

A todas as pessoas do Lar Padre Euclides que, de uma forma ou de outra, contribuíram na minha formação.

À Bernadete, da Sala de Leitura, pela ajuda ímpar com as referências bibliográficas.

À Adriana, do DEPCH, pelas informações certas nas horas certas.

A muitas outras pessoas que não foram citadas, mas que exerceram sua parcela de "culpa" para que hoje estivesse onde estou.

Meus sinceros agradecimentos. 


\section{RESUMO}

HADDAD, D.F. Vivências de perda e luto de idosos residentes em uma instituição asilar de longa permanência em Ribeirão Preto-SP. 2008. 64f. Dissertação (Mestrado) - Escola de Enfermagem de Ribeirão Preto/USP, Ribeirão Preto, 2008.

A institucionalização acarreta perdas ao idoso que devem ser elaboradas por um processo de luto, de caráter patológico quando insatisfatório, sendo, certamente, a maior causa de depressão na idade avançada. Idosos residentes em instituições de longa permanência apresentam uma multiplicidade de perdas. O presente estudo objetivou investigar situações de perda e luto de idosos institucionalizados. Trata-se de estudo qualitativo; descritivo e exploratório. Os critérios de inclusão foram: idade igual ou superior a 60 anos, capacidade de entendimento e comunicação verbal e concordância com o Termo de Consentimento Livre e Esclarecido. Foram realizadas entrevistas semiestruturadas, com seis idosos, que foram gravadas em fita cassete e submetidas à análise de conteúdo. Foram elaboradas três categorias: perda por morte, perda por separação e outras perdas; sendo a perda por separação dividida em três subcategorias: separação conjugal, separação da família e separação de companheiros da instituição. A morte de pessoas queridas aproxima o idoso de sua própria mortalidade dificultando o processo de luto; porém, a separação é muito mais difícil de ser elaborada por ser uma perda entre vivos, com possibilidade de se perder o significado da vida junto com o outro. Assim, a separação pode ser mais temida que a própria morte. Considera-se, portanto, que é fundamental aos cuidadores asilares conhecer as diversas situações de perdas e luto do idoso institucionalizado, a fim de auxiliá-lo em seu processo de enfrentamento, fornecendo subsídios para que o asilamento não seja vivenciado como uma experiência desagradável.

Palavras-chave: Idoso. Institucionalização. Luto. 


\begin{abstract}
HADDAD, D.F. Experiences of loss and grief of elderly living in a nursing home at Ribeirão Preto-SP. 2008. Dissertation (Master) - Ribeirão Preto Nursing School/USP, Ribeirão Preto, 2008.

For the elderly, life in a nursing home may result in a multitude of losses which must be addressed by the individual through the process of grief. This process, when pathologic, may not be sufficient, becoming a major catalyst for depression among seniors. The objective of this study was to investigate situations of loss and grief among institutionalized seniors. It is a qualitative, descriptive and exploratory research. Including criteria: individuals 60 years or older who had the ability to comunicate and understand, agreeing with the Consent Term. Half-structured interviews conducted with six people were recorded and submitted to "contents analysis" (Minayo's method). Three categories of emotional loss were created: loss by death, loss by separation and other losses. Loss by separation was further divided into three subcategories: marriage separation, family separation and separation of peers living in the nursing home. The death of a loved one reminds the elderly individual of his/her own mortality, complicating the process of mourning. Separation, however, is much more difficult to overcome because there is a loss among the living, with the possibility to lose the meaning of life with the other one. Therefore, separation may cause more fear than death itself. Finally, understanding loss and grief among the elderly people is fundamental for nursing care, in order to help them with the process of coping and to prevent institutionalization to become an unpleasant experience.
\end{abstract}

Key words: Elderly. Institutionalization. Grief. 


\title{
RESUMEN
}

\begin{abstract}
HADDAD, D.F. Vivencias de pierda y luto en ancianos residentes en una instituición asilar de longa permanencia en Ribeirão Preto-SP. 2008. 64f. Disertación (Maestría) - Escuela de Enfermería de Ribeirão Preto/USP, Ribeirão Preto, 2008.
\end{abstract}

La institucionalización acarrea pierdas a los ancianos que deben ser elaboradas con un proceso de luto, de carácter patológico cuando insatisfactorio, sendo, ciertamente, la mayor causa de depresión en la edad avanzada. Ancianos residentes en instituciones de longa permanencia presentan una multiplicidad de pierdas. Este estudio objetivó investigar situaciones de pierda y luto de ancianos institucionalizados. Tratase de un estudio cualitativo; descriptivo y exploratorio. Los criterios de inclusión fueron: edad igual o arriba de 60 años, capacidad de entendimiento y comunicación verbal y concordancia con el Termo de Consentimiento. Fueron hechas entrevistas semeestructuradas, con seis ancianos, que fueron grabadas en casetes e después transcritas y sometidas a "análisis de contenido". Fueron elaboradas tres categorías: pierda por muerte, pierda por separación y otras pierdas; sendo la pierda por separación dividida en tres subcategorías: pierdas de conyugales, pierdas familiares y pierdas de otros compañeros de la institución. La muerte de personas queridas acerca el anciano de su propia mortalidad, dificultando el proceso de luto; en tanto, la separación es muy más difícil de ser elaborada por ser una pierda entre vivos, con posibilidad de perderse el significado de la vida junto con el otro. Así, la separación puede ser más temida que la propia muerte. Considerase, por tanto, que es fundamental a la asistencia conocer las situaciones de pierdas y lutos de ancianos institucionalizados, con el intuito de ayudarlos en este enfrentamiento, forneciendo subsidios a la institucionalización para que esta no sea una experiencia desagradable.

Palabras clave: Ancianos. Institucionalización. Luto. 


\section{LISTA DE ILUSTRAÇÕES}

Quadro 1. Artigos encontrados nas bases eletrônicas segundo os descritores selecionados 


\section{SUMÁRIO}

1. PALAVRAS INICIAIS

1.1. Sobre a escolha por fazer pesquisa

1.2. Sobre a pesquisa que escolhi fazer

2. PROCESSO DE DESENVOLVIMENTO E

ENVELHECIMENTO

3. ENVELHECIMENTO POPULACIONAL MUNDIAL

E INSTITUCIONALIZAÇÃO

4. PERDAS E PROCESSO DE LUTO

5. REVISÃO DA LITERATURA

5.1. Estratégia de busca do material 18

\section{OBJETIVO}

7. RECURSOS METODOLÓGICOS 22

7.1. Método clínico-qualitativo 22

7.2. Local 23

7.3. Sujeitos 25

7.4. Aspectos éticos 26

7.5. Coleta e processamento dos dados 26

8. RESULTADOS 32

8.1. Apresentação dos sujeitos $\quad 32$

9. DISCUSSÃO 37

9.1. Perda por morte $\quad 37$

9.2. Perda por separação $\quad 42$

9.2.1. Separação conjugal 42

9.2.2. Separação da família $\quad 47$

9.2.3. Separação de companheiros da instituição $\quad 50$

9.3. Outras perdas 51

10. CONSIDERAÇOES FINAIS 53

11. REFERÊNCIẢS BIBLIOGRÁFICAS

ANEXO 61

Anexo A - Parecer de aprovação no CEP/EERP/USP 61 APÊNDICES

Apêndice A - Termo de Consentimento Livre e Esclarecido

63

Apêndice B - Roteiro da entrevista 


\section{PALAVRAS INICIAIS}

\subsection{Sobre a escolha por fazer pesquisa}

Meu interesse em fazer pesquisa surgiu com o primeiro levantamento bibliográfico, ainda na graduação em enfermagem, quando realizava o trabalho de Iniciação Científica. O tema era qualidade do sono de idosos no pós-infarto agudo do miocárdio. Chamou-me atenção o modo especial como a presença da pesquisadora parecia estimulá-los.

Sentia-me útil buscando conhecer, descobrir e contribuir com os idosos, sujeitos da pesquisa. Sujeitos que me dariam subsídios para obter os resultados da pesquisa e que por isso eram, na verdade, os mais importantes, pois, sem eles, os objetivos do estudo não seriam atingidos e não haveria possibilidade de construir novos conhecimentos.

\subsection{Sobre a pesquisa que escolhi fazer}

Ao concluir o curso de graduação em Enfermagem, buscando complementar minha formação, ingressei no Curso de Especialização em Enfermagem Psiquiátrica e Saúde Mental do Departamento de Enfermagem Psiquiátrica e Ciências Humanas da Escola de Enfermagem de Ribeirão Preto da Universidade de São Paulo - DEPCH/EERP/USP. Luto era um dos temas propostos para ser estudados no trabalho de Conclusão de Curso, pelo qual me interessei, desenvolvendo meu estudo sobre o luto dos usuários de droga. $\mathrm{O}$ tema sempre me chamou a atenção pois não entendia como a morte apavorava a todos se era uma das poucas certezas, senão a única, que temos em vida e que deveria ser compreendida e enfrentada.

A idéia de pesquisar o luto em idosos institucionalizados surgiu durante minha atuação como enfermeira de uma instituição asilar de longa permanência. Percebi neles a necessidade de compartilhar sentimentos, alegrias e tristezas.

Porém, percebi também que os relatos de situações tristes superavam os de momentos alegres e muitos deles vinham até mim com o objetivo de dividir suas tristezas 
como tentativa de alívio do seu sofrimento. No começo, pensei que se tratava apenas de desabafo e carência afetiva, no entanto, ao ouvir tantas histórias tristes, fiquei me perguntando o que essas vivências significavam para eles. Percebi, então, que a maioria dos relatos relacionava-se a variadas situações de perdas ocorridas ao longo de suas vidas.

Foi quando nasceram em mim as primeiras intenções em realizar uma pesquisa qualitativa com esses idosos, a fim de conhecer suas vivências de perda e luto, na tentativa de compreender seu significado para o idoso enlutado e poder assisti-lo da melhor maneira possível em sua individualidade. 


\section{PROCESSO DE DESENVOLVIMENTO HUMANO E ENVELHECIMENTO}

O significado original da palavra desenvolvimento é "adiantamento, crescimento, aumento, progresso" (FERREIRA, 1988; p. 211). A vida adulta, bem como a velhice, não era considerada pela psicologia da criança e do adolescente, pois se acreditava que o desenvolvimento cessava após essas duas fases. Que na vida adulta eram mantidas as aquisições de até então e que nos anos da maturidade e da velhice só ocorria degeneração (NERI, 2001b)

As teorias sociológicas clássicas sobre o envelhecimento - teoria da atividade, do desengajamento, da modernização, da subcultura, entre outras - datam de mais de 40 anos, quando a paisagem sociodemográfica era diferente, mesmo nos países desenvolvidos: à época, acreditava-se no poder explicativo de grandes teorias. Acerca do envelhecimento, essa crença foi derrotada pela evolução subseqüente da gerontologia social, hoje caracterizada pela atuação de várias microteorias.

Essas teorias foram baseadas no contexto norte-americano, sendo uma das críticas feitas a elas o fato de não abrangerem as peculiaridades nacionais e regionais, uma vez que o processo de envelhecimento é heterogêneo, podendo ocorrer de forma diferente para indivíduos em contextos históricos e sociais distintos (NERI, 2001a). Segundo a autora, essa diferenciação depende de influências culturais, de fatores intelectuais e de personalidade e da incidência de patologias durante o envelhecimento normal. Apesar das críticas, não se pode negar a forte influência que as teorias clássicas da gerontologia social tiveram sobre a prática de atendimento ao idoso no contexto brasileiro.

Dessa forma, os estágios do desenvolvimento, de acordo com Neri (2001a), são de origem sociogenética, pois cursos de vida são construídos pela sociedade à medida que estipula expectativas e normas de comportamento apropriado para as diferentes idades e à medida que elas são internalizadas, tanto pelos indivíduos quanto pelas instituições sociais.

Assim, o desenvolvimento pode ser analisado como uma seqüência de mudanças previsíveis que ocorrem ao longo das idades - mudanças psicossociais determinadas pelos 
processos de socialização a que as pessoas estão sujeitas; e como uma seqüência nãoprevisível de alterações resultantes da influência biológica e social (NERI, 2001a).

O processo inevitável do envelhecimento provoca no organismo modificações biológicas, psicológicas e sociais (SANTOS, 2003). Do ponto de vista biológico, envelhecer não é apenas ficar velho, mas vivenciar um processo de mudanças morfológicas e fisiológicas à medida que o tempo passa (NERI, 2001a; SANTOS, 2003). As modificações psicológicas são as adaptações que necessitam serem feitas em cada situação desconhecida do cotidiano (SANTOS, 2003). Já o envelhecimento social é o processo de mudança e adequação dos papéis e dos comportamentos dos adultos mais velhos ao que é normalmente esperado para essa faixa etária (BIRREN; SCHROOTS, 1984).

Martins (2002) destaca que, muitas vezes, os fenômenos do envelhecimento e da velhice são considerados pelas restritas modificações que ocorrem na dimensão física, porém, devem ser igualmente reconhecidas as mudanças na forma de pensar, de sentir e de agir dos seres humanos que vivenciam essa etapa do desenvolvimento. É nesse sentido que a maturidade - qualidade individual e social desejável - distingue-se da velhice - problema individual e social a ser evitado (NERI, 2001a).

Reconhecer que o idoso comporta experiências a serem compreendidas é clarificar ao mundo dos homens que delas resulta uma maturidade alcançada individual e coletivamente. Logo, a maturidade supõe um processo permanente de aprendizagem, troca e continuidade que estabeleça um lugar para o velho e a velhice (NERI, 2001a).

A velhice é, então, definida por diversos autores de acordo com os aspectos considerados. Beauvoir (1990) entende velhice como o que acontece aos seres humanos que ficam velhos, sendo impossível encerrar essa pluralidade de experiências num conceito. Bobbio (1997) admite que a velhice não deve ser uma cisão mas uma continuação da infância, da adolescência, da juventude e da maturidade, vividas de diversas maneiras. Já Martins (2002) a considera um conceito abstrato, que diz respeito a uma categoria socialmente criada para demarcar o período em que os seres humanos ficam envelhecidos. De maneira sutil, Bobbio (1997) ainda lembra as limitações e perdas trazidas pela velhice, correlacionando o processo de envelhecimento com situações de perdas e com a morte. 
Nesse contexto, vale ressaltar que o termo "envelhecimento", em português, é formado a partir do radical "velho", termo que em seu sentido imediato traz a imagem de algo decrépito, decadente, que perdeu o uso, a validade. Por isso, o processo, bem como seu significado, é visto como deprimente. Outras culturas utilizam termos que não remetem à idéia de decrepitude, como no português. Em inglês, por exemplo, envelhecimento é aging, derivado do radical age - idade - (apesar de existir o termo old para designar velho), sendo o sentido de aging o de acrescentar idade. Também em japonês é utilizado o termo karei ( $k a$ - somar, acrescentar; e rei - tempo de vida). Duas culturas completamente distintas, uma ocidental e outra oriental, que compartilham a prática de melhor expressar o termo envelhecimento (NERI, 2001a).

Desse modo, resiste-se a envelhecer, negando-se o que é considerado um ganho da velhice: a maturidade, que nos dá subsídios para viver bem e melhor. A resistência ao envelhecimento, por conseguinte, confronta-se com uma dimensão interior em que o indivíduo busca não se perder, não ser negado (NERI, 2001a).

Para resistir à finitude da vida, vão todos em busca de alternativas oferecidas pelo mundo do lucro e do capitalismo: as inúmeras práticas de rejuvenescimento; o consumo de complexos vitamínicos; o mundo dos cosméticos. A ideologia da velhice quer deixar transparecer a imagem de um velho mais dinâmico, atingindo homens e mulheres da chamada terceira idade - na opinião de Motta (1998), eufemismo usado por esse mercado para tornar a velhice pretensamente mais aceitável, mas que acarreta ambigüidades entre os idosos e a própria velhice e entre os idosos e a sociedade. Seus sinais são ora a negação e marginalização da velhice, aparentada como feia, ora sua valorização e até mesmo aceitação de que os idosos lutem por seus direitos (MOTTA, 1998).

Por tudo isso, a velhice e o envelhecimento em nossa sociedade, dita moderna, são partes de um processo paradoxal sintetizado pelo sistema social no qual o velho oscila em ser e não ser parte integrante das relações sociais, ter e não ter um lugar e um papel a si e à sua experiência consolidada pela maturidade (NERI, 2001a). 

INSTITUCIONALIZAÇÃO

O crescimento da população idosa, em números absolutos e relativos, é um fenômeno mundial e está ocorrendo em um nível sem precedentes. Em 1950, eram cerca de 204 milhões de idosos no mundo; já em 1998, esse contingente alcançava 579 milhões de pessoas - um crescimento de quase 8 milhões de idosos por ano. As projeções indicam que, em 2050, a população idosa será de 1,9 bilhões de pessoas (IBGE, 2000).

Ainda segundo o Instituto Brasileiro de Geografia e Estatística - IBGE (2000)- a população de idosos no Brasil representa um contingente de quase 15 milhões de pessoas com 60 anos ou mais de idade (8,6\% da população). Nos próximos 20 anos, a população idosa brasileira poderá ultrapassar os 30 milhões de pessoas e deverá representar quase $13 \%$ da população.

A longevidade é uma das explicações para o aumento de idosos na população mundial, exemplificada pelo fato de o grupo das pessoas de 75 anos ou mais de idade ter tido o maior crescimento relativo $(49,3 \%)$ nos últimos dez anos, em relação ao total da população idosa. Bem como o aumento de 19 anos na esperança de vida ao nascer em todo o mundo, verificado desde 1950, e o declínio tanto das taxas de fecundidade como das de mortalidade (KALACHE; VERAS; RAMOS, 1987; IBGE, 2000).

A Organização das Nações Unidas, ONU, define o idoso como aquele com 60 anos de idade ou mais para os países em desenvolvimento, admitindo-se 65 anos para os países desenvolvidos. Essa definição foi estabelecida através da Resolução 39/125 - durante a Primeira Assembléia Mundial das Nações Unidas sobre o Envelhecimento da População, em 1982 - a partir da expectativa de vida ao nascer e da qualidade de vida dos cidadãos. No Brasil, é considerado idoso quem tem 60 anos e mais (ONU, 1982; BRASIL, 1996).

Santos (2003) ressalta que, apesar de o critério cronológico ser dos menos precisos, é um dos mais utilizados para estabelecer o ser idoso, até para delimitar a população de um determinado estudo, ou para análise epidemiológica, ou com propósitos relacionados a políticas públicas ou oferta de serviços. No entanto, o idoso não pode ser definido somente 
a partir do plano cronológico, pois outras condições - físicas, funcionais, mentais e de saúde - podem influenciar diretamente na determinação de quem o seja.

No Brasil, existem, desde a década de 90, três documentos oficiais relacionados à Política Nacional do Idoso e à Política Nacional de Saúde do Idoso: a Lei 8.842/94, sancionada pelo Ministério da Saúde em 1994, o Decreto Federal 1948/96 e a Portaria 1395/99, que têm por objetivo assegurar os direitos sociais do idoso, criando condições para promover sua autonomia, integração e participação efetiva na sociedade. Um de seus artigos trata o envelhecimento populacional como uma questão de interesse da sociedade em geral (BRASIL, 1994; 1996; 1999).

Em conseqüência desse aumento da população idosa no mundo verifica-se também um aumento da demanda por instituições de longa permanência, tanto em países desenvolvidos como em desenvolvimento. A drástica queda da taxa da fecundidade reduz a disponibilidade de cuidadores domiciliares. A redução do potencial de cuidados providos pelas mulheres, entre 1960 e 1990, observada em alguns países europeus, deverá ocorrer de modo ainda mais rápido no Brasil nos próximos anos. A participação feminina no mercado de trabalho retira do domicílio a figura tradicionalmente convocada para os cuidados dos idosos; novos arranjos familiares - mulheres sós, mães solteiras, casais sem filhos, filhos que emigraram - reduzem a perspectiva de envelhecimento em um ambiente familiar seguro (KINSELLA, 1996; CHAIMOWICZ, 1998; CHAIMOWICZ; GRECO, 1999).

De acordo com esses autores, a "transição social" que aumentou as taxas de institucionalização em outros países, ou seja, o aumento do número de indivíduos residindo em asilos em relação à população da mesma faixa etária, também tem ocorrido no Brasil. Fatores de risco para a institucionalização como morar só, suporte social precário e baixa renda (associada à viuvez, aposentadoria, pouca oportunidade de empregos formais e estáveis e aumento dos gastos com a própria saúde) são cada vez mais freqüentes no Brasil, bem como a presença de doenças crônico-degenerativas e suas seqüelas, hospitalização recente e dependência para realizar atividades da vida diária.

Nos Estados Unidos, por exemplo, cerca de 5\% dos idosos residem em abrigos, porém, diferentemente do quadro vigente no Brasil, essas instituições oferecem serviços de saúde, lazer e assistência social. Na Inglaterra, a freqüência da institucionalização do idoso é minimizada com o atendimento dessa população em hospitais-dia, com assistência 
multidisciplinar à saúde, especialmente na área da reabilitação, prestando-se, em sua maioria, para "aliviar" o trabalho dos familiares cuidadores de idosos dependentes (CHAIMOWICZ, 1998).

Como visto, o prolongamento da vida não ocorre isoladamente. Com o aumento da expectativa de vida da população, as instituições de longa permanência, que oferecem assistência aos idosos, tornam-se cada vez mais necessárias. Além disso, fatores como: perda de autonomia - decorrente de incapacidades físicas e mentais -, ausência da família para prestar cuidados e insuficiência de aporte financeiro do idoso e/ou seus familiares fazem com que as instituições de assistência aos idosos sejam cada vez mais solicitadas (PEREIRA et al., 2005).

Portanto, se as instituições para idosos, antes, eram destinadas à velhice desvalida, na sociedade atual, marcada pelo envelhecimento, passam a ter um novo objetivo: prestar cuidados a idosos que apresentam necessidade de uma assistência multiprofissional, em face às perdas funcionais, de origem física ou psicológica, que tornaram problemática a vida a sós ou com a família (PEREIRA et al., 2005).

Data de 1989 a Portaria n $^{\circ} 810$ do Ministério da Saúde que trouxe as normas para o funcionamento de casas de repouso, clínicas geriátricas e outras instituições destinadas ao atendimento de idosos no Brasil, quanto à definição, organização, área física e recursos humanos (BRASIL, 1989). Todavia, apesar da regulamentação, muitas instituições continuaram funcionando sem possuírem as condições ideais e, ainda que recebessem aval para funcionarem, o atendimento prestado à população idosa não apresentava a qualidade desejável. (YAMAMOTO, DIOGO; 2002).

Segundo Davim et al. (2004), normalmente, os asilos costumam surgir das necessidades sociais da comunidade, de forma espontânea, acarretando na deficiente qualidade de vida que os residentes lá encontram. De acordo com Silva (1997), as instituições asilares brasileiras voltadas ao idoso são locais com área física comparáveis a grandes alojamentos; raras são as que possuem recursos humanos especializados para assistência social e à saúde, ou proposta de trabalho coerente em manter o idoso independente e autônomo.

Silva (1997) descreve que idosos institucionalizados vivem como se estivessem em reformatórios ou internatos, obedecendo a regras de horário e limites de entrada e saída, e 
com pequena possibilidade de vida social, afetiva e sexual ativa. Na realidade, muitas vezes são encontrados verdadeiros depósitos, que, com fundamentação na premissa de amor ao próximo e amparo aos desabrigados, consideram o abrigo e os cuidados prestados suficientes às pessoas que estejam em seus últimos dias de vida.

Em vista disso, surge o Estatuto do Idoso, regido pela Lei no. 10.741 , de $1^{\circ}$ de outubro de 2003, a fim de disseminar os direitos constitucionais dos idosos, no Brasil, bem como uma melhor regulamentação do funcionamento das entidades de atendimento ao idoso, a fim de garantir a qualidade do atendimento prestado (BRASIL, 2003).

Vieira (1996) afirma que os asilos - a mais antiga, e universal, modalidade de atendimento ao idoso fora do seu convívio familiar (BRITO; RAMOS, 1996) -, geralmente, são casas inapropriadas e inadequadas às suas necessidades, as quais não lhes oferecem assistência social, bem como cuidados básicos de higiene e alimentação. Além disso, elas também dificultam as relações interpessoais, necessárias à manutenção da vida do idoso em comunidade e à construção de sua cidadania, e apresentam como inconveniente o favorecimento ao isolamento e à inatividade física e mental, acarretando em conseqüências negativas à qualidade de vida.

No Brasil, a miséria e o abandono são os principais motivos da institucionalização, apesar de grande parcela dos idosos institucionalizados apresentarem grau de dependência por problemas físicos ou mentais (CHAIMOWICZ,1998). São percebidos nesses idosos, conforme descrito por Pereira et al. (2005): nível elevado de sedentarismo, carência afetiva, perda de autonomia, ausência de familiares para auxiliar no autocuidado e condições financeiras insuficientes; fatores que refletem negativamente nos padrões de independência e autonomia.

O envelhecimento de sua população é uma aspiração natural de qualquer sociedade (KALACHE; VERAS; RAMOS, 1987). Porém, essa aspiração, por si só, não é o bastante. E é igualmente importante almejar uma melhoria da qualidade de vida daqueles que já se encontram na fase da velhice ou que estão em processo de envelhecer.

Sabendo que as estimativas apontam para demanda por asilos ainda maior no futuro próximo - a fase de crescimento rápido da proporção de idosos no Brasil deverá se iniciar por volta de 2010 (MACHADO, 1993) - a implementação de políticas de fiscalização e 
suporte às instituições asilares de longa permanência deveria antecipar-se ao aumento inevitável da demanda por vagas nas próximas décadas. 


\section{PERDAS E PROCESSO DE LUTO}

O processo de desenvolvimento humano envolve equilíbrio constante de ganhos e perdas, ocorrendo alterações da proporcionalidade entre eles ao longo do curso de vida: na infância, preponderam ganhos; na velhice, perdas (NERI, 2001a). Assim, é inevitável ao indivíduo vivenciar inúmeras perdas ao longo de seu desenvolvimento. Perdas são experiências universais que ocorrem de modo particular e peculiar a cada ser humano, individualizando-o (KOVÁCS, 1992; BROMBERG, 1996).

As perdas não são representadas somente pela morte em si, mas por diversas "pequenas mortes" ao longo das fases evolutivas, como perda do emprego, da posição social, de residência, entre outras, incluindo também as perdas relacionadas aos papéis que devem ser abandonados ao longo da infância, adolescência, vida adulta e velhice (KALISH, 1981; KOVÁCS, 1992; LALIVE D’EPINAY et al., 2003; MALKINSON; BAR-TUR, 2004-2005).

A cada um desses eventos estressantes, é necessário que o indivíduo elabore a conscientização das perdas, desencadeando o início de um processo de luto. Esse processo de reação à perda desenvolve-se de acordo com quatro fases: torpor ou aturdimento; saudade e busca da figura perdida; desorganização e desespero; e por fim a fase de reorganização, que pode ser de maior ou menor grau. O trabalho de luto faz-se necessário para que o indivíduo seja capaz de construir novos vínculos com os objetos que permaneceram e dar continuidade à sua vida (BOWLBY, 1990; BROMBERG et al., 1996; PARKES, 1998).

O luto saudável é alcançado com a aceitação das modificações do mundo externo e, conseqüentemente, interno e representacional do indivíduo, com a reorganização psíquica e a retomada da vida e das atividades do cotidiano (BARREIRA; VIEIRA, 2004; GAZALLE et al., 2004). No entanto, é importante ressaltar que durante todo o processo de luto normal ocorre uma série de reações no indivíduo: alarme - ansiedade, inquietação; raiva e culpa; desânimo, cessação de interesses, perda da capacidade de amar, inibição de atividades externas; entre outras (HAIG, 1990; PARKES, 1998). Além da dor e do sofrimento, que são reações universais às perdas e separações (BOWLBY, 1985; 1990). 
Estar alegre e parecer feliz é quase um dever, socialmente imposto. Às vezes, tem-se de conceder permissão ao sofrimento. A dor é importante, também é o luto - desde que não paralise o indivíduo demasiadamente, por demasiado tempo, para o que ainda existe em torno de si (LUFT, 2005).

A qualidade dos sintomas expressados no processo de luto, bem como a duração do tempo de cada uma de suas fases, mesmo havendo um padrão, não segue uma regra, mas assume formas diferentes de acordo com a individualidade de cada ser humano. Um dos fatores que influenciam o luto de maneira importante é a qualidade do vínculo do enlutado com o objeto perdido (BOWLBY, 1990; WASKOVIC; CHARTIER, 2003). Luft (2005) afirma que o apoio dos outros, o abraço, o ouvido e o colo são relativos e passageiros, e que a força decisiva para enfrentar o processo de luto deverá vir de dentro de nós, de onde foi depositada nossa bagagem.

Nesse sentido, a teoria do apego, de Bowlby (1985), explica a necessidade do ser humano em estabelecer vínculos ao longo da vida como necessidade básica e vital, tendo assim, valor de sobrevivência para todas as espécies. A figura vincular é aquela que oferece segurança ao indivíduo para a exploração do meio, de modo que, em situações de ameaça, possa distanciar-se do estímulo ameaçador e se proteger junto à figura de vínculo (BROMBERG et al., 1996). Assim, o apego inicial será a matriz sobre a qual todos os vínculos posteriores se desenvolverão, a matriz sólida para os relacionamentos futuros (BERTHOUD; BROMBERG; COELHO, 1998).

O primeiro caso de amor da criança começa antes mesmo à concepção, posto que esta será influenciada pelo desejo, por vezes inconsciente, de seus pais. Assim, ela existe como possibilidade antes de se materializar na fertilização. $O$ bebê traz em sua bagagem hereditária uma predisposição para apegar-se a outro indivíduo que lhe seja acolhedor e receptivo; e ele vai conquistando, progressivamente, por meio do sorriso, da sucção, do agarrar-se, do balbucio, do choro e da locomoção, sua primeira parceira de interação - a figura materna (BERTHOUD; BROMBERG; COELHO, 1998). Assim, o bebê organiza sua primeira representação interna da figura de apego - o amor primeiro - e, conseqüentemente, surge o início da ansiedade da separação quando a figura de apego se afasta (AINSWORTH, 1989). 
Há indícios de que o padrão de apego a ser desenvolvido da idade adulta seria uma evolução do apego estabelecido na infância. Ao iniciar a idade adulta, provavelmente após ter experienciado diversos tipos de relações afetivas na adolescência, o indivíduo vivencia uma fase final de transformação do sistema de apego. Nesse momento, a figura principal de apego estabelecida na infância deslocar-se-á para um parceiro, que servirá de base segura a partir da qual as vivências da vida adulta se tornarão possíveis (BERTHOUD; BROMBERG; COELHO, 1998).

Segundo essas autoras, além de desenvolver apego em relação ao parceiro, o indivíduo adulto deve também ser capaz de desenvolver forte apego por seus filhos, e, assim, adquirir a condição de viver plenamente a paternidade, completando a circularidade do processo de desenvolver laços profundos e duradouros com nossos semelhantes, que se tornam para nós pessoas tão significativas.

Os seres humanos constroem muitos vínculos ao longo da vida e, sendo esses tão consideravelmente importantes à condição de ser social, pode-se dizer que a vida está associada à maneira como os relacionamentos são organizados. É preciso uma rede de relacionamentos interpessoais que supra as diversas necessidades: de amizade, de companheirismo, de amor, de paixão, de satisfação sexual; enfim, vínculos - passageiros e duradouros - que dão sentido à existência humana (BERTHOUD; BROMBERG; COELHO, 1998).

Segundo Bowlby (1978), o estabelecimento inicial de vínculos ocorre na infância, de acordo com quatro fases. Primeiramente, a criança mostra orientações e sinais, como voltar-se para uma pessoa, seguir objetos com os olhos, sorrir e balbuciar, sem ser para uma pessoa específica. Após a fase inicial, ocorre um direcionamento dessas orientações e sinais a uma ou mais figuras discriminadas - acentuadamente para a mãe. Posteriormente, ocorre uma manutenção dessa proximidade da criança com a figura discriminada, momento em que se torna evidente a relação vincular, para, finalmente, ocorrer a formação de uma parceria definitiva.

A qualidade do vínculo estabelecido primariamente determinará os vínculos futuros e os recursos que serão utilizados no enfrentamento de perdas e separações. Assim, esses vínculos podem apresentar-se de diferentes maneiras, o que influenciará no processo de luto. Se for do tipo ansioso, marcado por separações e relações de dependência, 
provavelmente haverá uma dificuldade maior em elaborar o luto, desencadeando mais facilmente sintomas negativos e somáticos. O contrário ocorre quando há um vínculo seguro, que permite o desenvolvimento da auto-estima e da autoconfiança, que facilitam a elaboração de um luto saudável (SABLE, 1989; BOWLBY, 1990; BROMBERG et al., 1996; BROMBERG, 2000; WASKOVIC; CHARTIER, 2003).

Entretanto, quando essas reações são exageradas e prolongadas, ou, pelo contrário, reprimidas e não expressadas, e a desorganização psíquica duradoura, assume o caráter anormal do luto, podendo chegar até a uma dimensão patológica - na qual o indivíduo enlutado é incapaz de enfrentar sua própria vida (PINCUS, 1989; BOWLBY, 1990; KOVÁCS, 1992; BROMBERG et al., 1996; PARKES, 1998; BROMBERG, 2000).

Quanto mais numerosos forem os episódios de perda, maior a probabilidade de processos de luto ocorrerem de forma anormal. Uma fase do desenvolvimento humano em que essas perdas são vivenciadas em grande quantidade é a velhice, considerada também como a fase em que a morte parece mais presente ao ser humano. É um período de grandes perdas pessoais - perda da vitalidade, separação da família, perdas financeiras, deficiências orgânicas e físicas - e sociais, como a aposentadoria e a incapacidade de produzir, discriminadas pela sociedade (BROMBERG et al., 1996; BROMBERG, 2000; WASKOVIC; CHARTIER, 2003).

A velhice é também uma fase caracterizada por resiliência e plasticidade comportamental diminuídas, ou seja, pela possibilidade de mudança para adaptar-se ao meio reduzida, bem como a capacidade de reagir e de se recuperar de eventos estressantes, físicos ou psicológicos (NERI, 2001a).

Assim, a multiplicidade de perdas vividas nessa fase do desenvolvimento é uma possível explicação para os problemas psicológicos conseqüentes do luto na idade avançada. Há evidências dessa vulnerabilidade dos idosos nos estudos de Brown e Harris (1978) sobre depressão, que apontaram a perda e a decepção como as características centrais de grande parte dos acontecimentos que desencadeiam o quadro de depressão clínica (BOWLBY, 1990; ROOS; HAVENS, 1991; PARKES, 1998).

Em outro estudo, conduzido por Gass (1989), os dados apresentados também vêm de encontro com a afirmação anterior sobre a multiplicidade das perdas. Nele, o autor 
afirma que viúvas que tinham outras ameaças além da perda do marido, como conseqüente perda da casa, do salário ou do status social, apresentavam maior risco de desenvolverem dificuldades psicológicas do que aquelas em que a morte do marido tivera sido a única situação de risco.

Parkes (1998) afirma que o luto, certamente, é a causa de depressão na idade avançada, podendo ser encontradas evidências nos achados de Clayton; Halikas; Maurice (1972), Duran; Turner; Lund (1989) e Lund; Caserta; Dimond (1989). Esses autores afirmam que em 10 a 17\% de viúvas idosas são esperados níveis de depressão equivalentes àqueles encontrados em clínicas psiquiátricas. Os estudos de Clegg (1988) também corroboram esses dados quando afirmam que entre 71 pacientes internados em uma enfermaria psicogeriátrica, 22 (31\%) haviam sofrido uma ou mais perdas por morte e, desses, dez (45\%) haviam tido outros tipos de perda, como da saúde ou da função.

As pessoas idosas, também, tendem a ser mais vulneráveis aos efeitos do luto na saúde física, como afirmou Rosenbloom (1993) ao demonstrar um aumento na taxa de mortalidade e uma diminuição da ingestão de nutrientes por viúvas mais velhas. Além disso, Richards e McCallum (1979) também evidenciaram que pessoas idosas, mais frágeis fisicamente, são mais vulneráveis à depressão após uma perda do que aquelas que se encontram bem fisicamente.

Os achados de Gazalle et al. (2004) em brasileiros corroboram com o descrito acima, acrescentando ainda que quanto mais avançada a idade, maior a média de aparecimento dos sintomas depressivos na população idosa. Afirma também que a resposta emocional desses indivíduos encontra-se diminuída, acarretando o predomínio de sintomas como: diminuição do sono, perda de prazer nas atividades habituais, ruminações sobre o passado e falta de energia.

Em se tratando de idosos institucionalizados, tomando por base minha experiência profissional como enfermeira assistencial de uma instituição asilar de longa permanência para idosos - Lar Padre Euclides - na cidade de Ribeirão Preto-SP, pude verificar que a existência de numerosas perdas nessa população é um fato real. A entrada do idoso nessa instituição, segundo um levantamento de dados no campo, normalmente é feita pela família, quando não há condições financeiras ou disponibilidade do familiar do idoso para o 
cuidado, ou, pelo próprio idoso, quando perde o parceiro ou sente-se incapaz de viver sozinho.

A partir da pesquisa de Burati (2002), percebe-se que essa é uma realidade atual dessa instituição, que, inicialmente, ainda como Asylo de Mendicidade de Ribeirão Preto, objetivou abrigar somente mendigos e moradores de rua. Relatos da época de sua inauguração, em 1919, e de quando começou a receber moradores - 1920 - mostram também que, no início, houve certa dificuldade em manter a ordem local devido ao comportamento dos asilados (BURATI, 2002).

Vivenciando a realidade asilar, pude notar que, mesmo havendo no Lar Padre Euclides uma vasta gama de atividades educativas, recreativas e de lazer, muitos idosos permanecem a maior parte do tempo isolados, sem entretenimento, não participam das atividades oferecidas, não se relacionam com os outros idosos ou até mesmo com os próprios funcionários, não conseguindo conviver harmoniosamente com ninguém. Alguns são vistos até como empecilho para a instituição, pois há regras que devem ser cumpridas e que são às vezes desrespeitadas para promover o bem-estar destes poucos, semelhante ao descrito na literatura.

Quando ocorre a institucionalização, o idoso passa por um processo de distanciamento de seus familiares, podendo até chegar ao abandono, desencadeando um desligamento do mundo no qual vivia e de sua história. Logo na admissão, os idosos perdem seus objetos pessoais e simbólicos, ponte de ligação entre seus sentimentos e seu eu (SILVA et al., 2007) e entregam-se às rotinas da instituição.

Silva et al. (2007) relatam que, mesmo em instituições com programação de atividades, a maioria dos idosos institucionalizados sente-se pressionada a tomar medicações, alimentar-se nos horários previstos, manter contatos pessoais indesejados e participar de atividades que não lhe agradam.

Assim, a própria institucionalização pode ser considerada uma situação de luto para o idoso, pois normalmente ocorre acompanhada do rompimento de vínculos como a separação da família, perda do companheiro, mudança de residência, perda da independência e/ou autonomia, mobilizando recursos internos e externos do idoso para recuperar sua identidade. Silva et al. (2007) ressaltam que esse pode se tornar um processo 
extremamente doloroso para o idoso institucionalizado devido à diminuição e, por vezes, a total ausência de apoio dos familiares.

Sabendo que o crescimento cada vez maior da população idosa é um fenômeno mundial, e que o Brasil terá, em 2025, a $6^{\text {a }}$ população mais velha do mundo (BARREIRA; VIEIRA, 2004; GAZALLE et al., 2004), aumenta a necessidade de "olharmos mais de perto" para o idoso em instituição asilar, visando compreender sua percepção acerca das experiências vividas.

Tendo em vista os dados apresentados, surgem inúmeros questionamentos. Como as perdas do processo de desenvolvimento influenciam na vida de pessoas idosas? Até que ponto processos de luto anteriores influenciam na ida ou não do idoso para uma instituição? Na maneira como o idoso vincula-se ou não às pessoas, qual o tipo de vínculo que se estabelece? De que maneira os vínculos anteriores e o rompimento destes influenciam na vida do idoso institucionalizado? A partir disso, ressalta-se a importância ímpar de um trabalho de investigação das vivências de idosos residentes em instituição, mesmo que essas questões não sejam totalmente compreendidas.

Considerando a escassez de pesquisas sobre o tema e a insuficiência de respostas na literatura específica, surge a necessidade de uma melhor investigação e compreensão acerca deste. Talvez, a posteriori, a apreensão das experiências do idoso institucionalizado possa contribuir para que haja uma possibilidade de melhora dos cuidados à saúde da população idosa no Brasil. 


\section{REVISÃO DA LITERATURA}

\subsection{Estratégia de busca do material}

O levantamento bibliográfico foi realizado através de cinco bases de dados: MedLine, PubMed, SciELO (Scientific Electronic Library Online), LiLACS (Literatura Latino-Americana e do Caribe em Ciências da Saúde) e PsycInfo e em visitas à Biblioteca Central do Campus de Ribeirão Preto da Universidade de São Paulo - USP/RP. Para que as buscas eletrônicas pudessem ser iniciadas foram escolhidos três descritores: idoso, luto e instituição, e seus respectivos em inglês - elderly, bereavement e nursing home. O quadro abaixo mostra o número de artigos encontrados quando cruzados os descritores acima:

\begin{tabular}{|l|c|c|c|c|c|}
\hline \multicolumn{1}{|c|}{ Base de Dados } & MedLine & PubMed & Scielo & LILACS & PsycInfo \\
Descritor(es) & & & & & \\
\hline Idoso & 1117587 & 04 & 429 & 5678 & 00 \\
\hline Idoso+luto & 02 & 00 & 01 & 03 & 00 \\
\hline Idoso+instituição & 5371 & 00 & 10 & 163 & 00 \\
\hline Idoso+luto+instituição & 00 & 00 & 00 & $\mathbf{0 1}$ & 00 \\
\hline Elderly & 55196 & 1601893 & 703 & 3797 & 638 \\
\hline Elderly+bereavement & 58 & 1397 & 00 & 09 & 40 \\
\hline Elderly+nursing home & 00 & 16349 & 00 & 83 & 75 \\
\hline Elderly+bereavement+ & 00 & $\mathbf{4 9}$ & 00 & 00 & 10 \\
nursing home & & & & & \\
\hline
\end{tabular}

Quadro 1 - Artigos encontrados nas bases eletrônicas segundo os descritores selecionados.

Como se pode observar, quando usamos somente a palavra idoso - elderly - como descritor obtemos um número bastante significativo de artigos; porém, quando cruzamos esse descritor com um dos outros dois selecionados esse número diminui consideravelmente. Como os sujeitos do nosso estudo são idosos institucionalizados com 
vivências de luto, somente 50 desses artigos - 49 localizados no PubMed e 01 no LiLACS - foram pormenorizados por apresentarem, a princípio, relação com os três descritores: idoso, luto e instituição/elderly, bereavement e nursing home.

Esses artigos foram analisados, portanto, quanto ao ano de publicação, idioma, acesso ao resumo ou ao texto completo, metodologia utilizada e objetivo do estudo.

Os artigos foram publicados entre os anos de 1976 a 2007, sendo que cinco deles datam entre 1976 a 1986, 15 são de 1987 a 1996 e 30 foram publicados desde 1997 até o ano atual. Percebe-se nos últimos dez anos um nítido aumento da prevalência de artigos relacionados ao tema, provavelmente devido à crescente preocupação com a população idosa e seu rápido crescimento mundial nos últimos tempos.

Os objetivos dos trabalhos analisados mostraram uma gama de investigações que foram feitas acerca da população idosa, sendo: descrever unidades de cuidados paliativos para idosos; determinar a extensão do estresse crônico de cuidadores de pacientes com Doença de Alzheimer; registrar os cuidados de uma enfermeira a um residente de instituição de longa permanência com câncer em estado terminal; descrever os resultados da musicoterapia a pacientes terminais; como diagnosticar e tratar depressão em idosos; comparar o processo de luto de cuidadores de pacientes demenciados que morreram em casa dos cuidadores de pacientes que morreram em instituições; avaliar se o uso da rivastigmina está relacionado a uma diminuição da terapia com antipsicóticos em residentes de instituições de longa permanência; entre outros.

No entanto, do total de resumos analisados, somente um único artigo apresentava-se diretamente relacionado com o tema, enquanto nos demais, os descritores eram citados, porém não traziam pessoas idosas como sujeitos, não estavam relacionados a instituições nem eram considerados aspectos de perda e luto relacionados à velhice ou à institucionalização, ou não se tratava de estudo qualitativo - critérios de seleção dos trabalhos - como percebido anteriormente pelas diferentes elucidações a que objetivavam os trabalhos.

Esse único artigo, citado no parágrafo acima, foi encontrado no SciELO, com publicação no ano de 2007 na revista Texto \& Contexto - Enfermagem, em português, intitulado "Vivendo após a morte de amigos: história oral de idosos". A pesquisa foi 
realizada por quatro pesquisadoras brasileiras - SILVA et al., 2007 - a partir de uma abordagem qualitativa.

O trabalho de Silva et al. (2007) objetivou revelar e compreender a vida do idoso após a morte do amigo de asilo, através de entrevistas e observação participante indireta. Participaram do estudo 15 idosos moradores de uma residência geriátrica em Salvador-BA. Os dados foram tratados através da análise de conteúdo e revelaram que a vida dos idosos passou por profundas alterações devido ao processo de luto e que surgiram características normais do luto não complicado: sentimentos, sensações físicas, cognições e comportamentos. Foi concluído que os idosos necessitam de atenção e acompanhamento dos profissionais cuidadores das residências geriátricas para que estes superem o luto de uma forma saudável e continuem vivendo.

Nas visitas à Biblioteca Central do Campus da USP/RP, foram encontrados sete trabalhos, todos publicados pela mesma revista científica, OMEGA - Journal of Death and Dying, nos últimos seis anos. Três deles tinham como tema a morte de pessoas queridas ocorrida na velhice, outros três abordavam a maneira de lidar com morte e perda e somente um considerava o processo de luto em idosos.

Dos sete estudos encontrados, dos quais dois eram apresentados como revisão bibliográfica, quatro faziam uso da metodologia quantitativa e somente um da qualitativa, sendo, inclusive, o único a ter considerado o processo de luto e pesar em idosos, citado anteriormente. O objetivo desse trabalho, realizado por Malkinson e Bar-Tur (2004-2005), foi identificar e caracterizar três fases principais do desenvolvimento do processo de luto em idosos, sendo atingido através da análise de 47 entrevistas realizadas com idosos enlutados por morte de filhos. 
6 OBJETIVO

Identificar e compreender experiências de perda e luto de idosos residentes em instituição asilar de longa permanência. 


\section{RECURSOS METODOLÓGICOS}

\subsection{Método clínico-qualitativo}

A abordagem qualitativa é relativamente recente, pouco mais de um século, ganhando status científico primeiramente com os antropólogos e psicólogos, vindo depois a ocupar um lugar nas áreas institucionais de saúde, com enfermeiros e médicos. Atualmente, dentre os profissionais com formação universitária na saúde, sobretudo nos Estados Unidos e Canadá, são os pesquisadores da área de enfermagem que vêm ganhando relevância, com vasta produção científica na literatura específica e promoção de eventos voltados para o assunto (TURATO, 2003).

Os métodos qualitativos dão ênfase às especificidades de um fenômeno em termos de suas origens e sua razão de ser (HAGUETTE, 1995). Para isso, segundo Greenhalgh e Taylor (1997), devemos ouvir o que as pessoas têm a nos dizer sobre determinados assuntos, ou seja, como elas nos contam que lidam com eles, que sentidos e significações elas atribuem a esses acontecimentos (TURATO, 2003).

Dentre as diversas modalidades de métodos de pesquisa qualitativa, foi escolhido o método clínico, que valoriza tanto a presença humana do sujeito como a do pesquisador no desenvolvimento da pesquisa, considerado por Bleger (1998) como um aspecto essencial quando se trata de ciência humana.

O método clínico-qualitativo foi escolhido para o desenvolvimento desse trabalho. Este método científico de investigação, conforme escreve seu próprio autor:

A partir das atitudes existencialista, clínica e psicanalítica, pilares do método, que propiciam respectivamente a acolhida das angústias e ansiedades do ser humano, a aproximação de quem dá a ajuda e a valorização dos aspectos emocionais psicodinâmicos mobilizados na relação com o sujeito em estudo, este método científico de investigação, sendo uma particularização e um refinamento dos métodos qualitativos genéricos das ciências humanas, e pondo-se como recurso na área da psicologia da saúde, busca dar interpretações a sentidos e a significações trazidos por tais indivíduos sobre múltiplos fenômenos pertinentes ao campo do binômio saúde-doença, com o pesquisador utilizando um quadro eclético de referenciais teóricos para a discussão no espírito da interdisciplinaridade. (TURATO, 2003; p.242) 
Partindo do pressuposto que a pesquisa qualitativa torna possível a investigação de crenças e atitudes sobre assuntos delicados em que uma relação de confiança pode permitir o acesso do pesquisador a dados que seriam inacessíveis quantitativamente (BRITTEN et al., 1995), a proposta do método clínico-qualitativo é trabalhar com esses assuntos de foro íntimo, normalmente acompanhados de angústias e ansiedades - existenciais e clínicas tais como aqueles referentes, sobretudo, à doença e morte (TURATO, 2003).

O estudo assumiu caráter descritivo e exploratório. A pesquisa exploratória permite ao pesquisador o aprofundamento em uma realidade empírica buscando conhecimentos para, em seguida, planejar uma pesquisa descritiva - cuja essência reside no desejo de conhecer a comunidade, seus traços característicos, a população a ser estudada, entre outros. Isso permite ao pesquisador obter mais conhecimentos em torno de um determinado problema, aumentando, assim, sua experiência acerca deste. Através do estudo exploratório, o pesquisador encontra os elementos necessários para obter os resultados que deseja, quando em contato com uma determinada população (MINAYO, 1989; TRIVIÑOS, 1994).

\subsection{Local}

A pesquisa qualitativa é multimetodológica quanto ao foco, e envolve uma abordagem interpretativa e naturalística, ou seja, os pesquisadores qualitativistas estudam as coisas em seu setting natural, na tentativa de dar sentido às significações que as pessoas trazem para eles (DENZIN; LINCOLN, 1994).

Buscando idosos no seu setting natural, onde podem falar com autoridade sobre o tema, a pesquisa foi desenvolvida no Lar Padre Euclides, inicialmente chamado Asylo de Mendicidade de Ribeirão Preto, localizado nos Campos Elíseos, na cidade de Ribeirão Preto-SP.

A instituição foi fundada em 1919, por Padre Euclides Gomes Carneiro, com o objetivo de abrigar mendigos e moradores de rua - pobres e desamparados -, tendo iniciado suas atividades em 1920, quando contava com três funcionários efetivos - uma lavadeira, um zelador e um cozinheiro - e ajudas voluntárias. No ano seguinte, puderam ser realizadas 
algumas melhorias na área física do asilo, como a construção de uma caixa d'água e o cercamento do terreno, com o auxílio de uma subvenção da Câmara Municipal de Ribeirão Preto.

Nessa época, os residentes dedicavam-se ao plantio de frutas, verduras e sementes e, posteriormente, ao cultivo de flores, à apicultura e à criação de animais, cujos lucros possibilitaram outros aprimoramentos nos aspectos físicos e de contratação de funcionários. Outra preocupação da época era manter nos asilados o exercício da religiosidade (BURATI, 2002).

Ainda de acordo com essa autora, o número de residentes no asilo aumentou progressivamente de 1920 a 1930 - não chegando, porém, a atingir sua capacidade máxima de 100 residentes - oscilando nos dez anos seguintes e estabilizando-se posteriormente. Inicialmente, no entanto, nem todos os asilados eram idosos, com predomínio da faixa etária entre 50 a 70 anos, deslocando-se para 60 a 80 anos na década de 40.

A denominação "Lar Padre Euclides" passou a ser utilizada somente a partir de 1979 (BURATI, 2002). Conta hoje com uma Diretoria formada por profissionais voluntários e por Irmãs da Congregação Filhas de Santa Tereza. Possui caráter filantrópico, vinculado ao Ministério de Ação Social, sendo mantido financeiramente pelas contribuições mensais dos idosos $(50 \%$ do valor dos recebimentos ou o que for adequado às condições econômicas de cada um), pelos aluguéis dos imóveis em nome da instituição, e também por uma subvenção mensal da Prefeitura de Ribeirão Preto.

Atualmente abriga 60 idosos, entre homens e mulheres, que podem residir em duas alas diferentes, de acordo com a necessidade de auxílio nas atividades de vida diárias e a dependência de cuidados específicos à saúde (como curativos, medicamentos endovenosos e subcutâneos, controle rigoroso de pressão arterial). Assim, 42 desses idosos são moradores das residências - por possuírem autonomia e independência -, e os 18 demais, dependentes de tais cuidados, permanecem em um espaço de fácil acesso aos cuidadores de enfermagem, chamado popularmente pelos idosos de "enfermaria".

As residências são divididas em quartos individuais ou para duas pessoas afins - do mesmo sexo (exceto em casos de parceiros casados) - havendo um sanitário comum a ser dividido por até quatro pessoas. Há um refeitório geral para homens e mulheres e um pátio 
onde ocorrem as recreações, bem como as aulas de Educação Física, Pintura e Alfabetização, ministradas por voluntários e profissionais contratados.

\subsection{Sujeitos}

$\mathrm{Na}$ pesquisa qualitativa, a amostragem não é simplesmente ditada pela conveniência. Consiste numa escolha deliberada de respondentes preocupada com a representatividade de uma amostra em relação à população total - chamada amostragem proposital, intencional ou deliberada (POPE; MAYS, 1995).

Assim, os sujeitos dessa pesquisa foram os idosos residentes no Lar Padre Euclides, de ambos os sexos, que obedeceram aos seguintes critérios de inclusão: idade igual ou superior a sessenta anos, capacidade de entendimento e comunicação verbal e que aceitaram participar do estudo assinando o Termo de Consentimento Livre e Esclarecido (APÊNDICE A), que foi previamente lido e explicado pelo pesquisador aos idosos.

A amostragem não foi previamente definida, visto que, segundo Minayo (1989), a pesquisa qualitativa não se baseia em um critério numérico para garantir sua representatividade. A amostragem boa é aquela que abrange a totalidade do problema investigado em suas múltiplas dimensões.

Com isso, a amostragem foi obtida por saturação, ou seja, o grupo de sujeitos foi fechado quando novas entrevistas apresentaram em seu conteúdo uma quantidade de repetições das informações coletadas com um número de sujeitos. Este fato representa que os elementos colhidos são satisfatórios à discussão visando os objetivos do projeto (TURATO, 2003). Dessa maneira, foram entrevistados seis idosos. 


\subsection{Aspectos éticos}

Foi solicitada uma autorização formal aos responsáveis pelo Lar Padre Euclides para que a coleta de dados pudesse ser realizada com idosos residentes na instituição. Após essa etapa, os residentes que corresponderam aos critérios de inclusão na pesquisa foram abordados individualmente pela pesquisadora, que fez uma apresentação prévia, explicando as finalidades e implicações da pesquisa e em que consistiria sua participação. Os idosos que concordaram em participar da pesquisa assinaram o Termo de Consentimento Livre e Esclarecido.

Através da leitura do Termo de Consentimento, com o uso de uma linguagem do senso comum, foi esclarecido ao sujeito que sua participação constituiria em uma entrevista, com horário e local previamente combinado. Este foi informado de que seu nome seria mantido em absoluto sigilo e que os dados coletados seriam utilizados para publicação científica, de acordo com os objetivos da pesquisa. Foi informado, ainda, de que sua participação deveria ser totalmente voluntária, com possibilidade de desistência a qualquer momento, sem nenhum tipo de prejuízo. Salientou-se também que não haveria gasto de qualquer natureza ao participar do estudo, e que teria total liberdade para solicitar maiores esclarecimentos sobre a pesquisa, se assim fosse necessário.

Atendendo os requisitos mínimos de protocolo de pesquisa com seres humanos, conforme Resoluções 196/96 e 251/97, o projeto foi encaminhado para o Comitê de Ética em pesquisa da Escola de Enfermagem de Ribeirão Preto da Universidade de São Paulo CEP/EERP/USP - e aprovado conforme protocolo número 0709/2006 (ANEXO A).

\subsection{Coleta e processamento dos dados}

Os instrumentos utilizados para a coleta de dados foram a entrevista não-diretiva e a observação.

A entrevista, além de ser o momento de encontro de pesquisador e sujeito, é considerada o instrumento fundamental do método clínico (MINAYO, 1989). Mucchielli (1994) explica a entrevista não-diretiva - também denominada de compreensão, de ajuda 
ou centrada no cliente - como um instrumento utilizado pelo pesquisador qualitativista com a finalidade de compreender o problema tal como o cliente o sente, com atitudes de interesse aberto e de não-julgamento, com autêntica intenção de compreender.

A observação, outro componente do trabalho de campo, consiste numa técnica em que o entrevistador percebe o comportamento global do sujeito entrevistado, fazendo anotações dos achados. Deve-se perceber o estilo e as alterações da fala bem como os múltiplos elementos da apresentação pessoal e em particular a comunicação não-verbal do informante, como a postura física, os gestos, as mudanças afetivas. Com o decorrer da entrevista, podem ocorrer alguns fenômenos no entrevistador em resposta às manifestações do sujeito; esses dados também devem ser devidamente registrados, constituindo a autoobservação (TURATO, 2003).

A entrevista foi do tipo semi-estruturada, mais corretamente chamada de semidirigida, para possibilitar ao entrevistador obter tanto dados objetivos quanto subjetivos. É conhecida como "conversa com finalidade" e deve partir de um roteiro préelaborado que serve de orientação ao pesquisador, como se fosse uma baliza, e não um cerceamento da fala do sujeito entrevistado. Os assuntos abordados na entrevista, bem como a ordem de aparecimento, são freqüentemente determinados pela ênfase que os entrevistados darão ao tema em pauta, sem necessariamente obedecer a uma seqüência rígida. Assim, tende a ter uma maior quantidade de material obtido e também maior grau de profundidade em relação ao questionário (MINAYO, 1989).

A entrevista - APÊNDICE B - foi composta por questões abertas, marcada apenas por tópicos disparadores, sem delimitação de respostas pré-estabelecidas, indo ao encontro de princípios qualitativos (TURATO, 2003).

Para May (1996), tal instrumento constitui um terreno seguro para o profissional de saúde, proporcionando um relatório de atividades coerente e investido de autoridade no campo da pesquisa qualitativa. Ela garante ao pesquisador obter as informações requeridas, ao mesmo tempo, permitindo ao cliente ter liberdade para responder e ilustrar conceitos (TURATO, 2003).

As entrevistas foram gravadas em fita cassete e transcritas na íntegra para posterior análise do material. O método utilizado para tal foi o da análise de conteúdo, que, segundo Britten (1995), é uma técnica para organizar o material transcrito segundo temas. Consiste 
em codificar o material com a finalidade de explicitar seu significado, podendo ser dividido em três momentos: o primeiro, das leituras flutuantes; o segundo, da categorização; e o terceiro, da apresentação dos resultados (TURATO, 2003).

Bardin (1995) descreve o primeiro momento como uma pré-análise para conhecer e estabelecer contato com o texto, deixando-se invadir por impressões e orientações. Já Lüdke e André (1986) afirmam que é o momento de ler e reler o material até chegar a uma “impregnação" de seu conteúdo. Após essa etapa, ocorre a classificação dos elementos do conjunto por diferenciação e, em seguida, por reagrupamento (que pode se dar por repetição ou relevância dos temas), para então finalizar com a apresentação dos resultados (TURATO, 2003).

As entrevistas foram realizadas após um encontro inicial de apresentação formal da pesquisadora ao idoso, que teve como objetivo informar sobre a pesquisa e realizar o agendamento da entrevista em si, como data, horário e local adequados a cada idoso, bem como leitura, esclarecimentos e assinatura do Termo de Consentimento Livre e Esclarecido, visando os princípios de liberdade e privacidade. Não foi, porém, estabelecido previamente um limite de tempo para sua duração, tendo sido, em média, de trinta a cinqüenta minutos. As entrevistas foram realizadas no período de julho a dezembro de 2007.

A primeira entrevistada foi contatada em uma de suas visitas à pesquisadora enfermeira da instituição. Diariamente, queixava-se de lombalgia de forte intensidade, mesmo na vigência do tratamento medicamentoso. Após a queixa, lembrou-se do marido falecido e começou a chorar, como fazia freqüentemente. A pesquisadora, então, intuiu que aquela senhora necessitava alguém para ouvi-la, com o propósito genuíno de escutar seus sentimentos. Nesse contexto, a idosa foi informada sobre a realização da pesquisa e sobre a importância de sua participação, como uma possibilidade de exteriorização de seus sentimentos e recordações.

A partir desse consentimento inicial, a entrevista foi agendada em horário e local conforme a preferência da idosa. Em alguns momentos, talvez por ter sido a primeira entrevista ou pela complexidade do tema, a pesquisadora sentiu-se impulsionada a confortar a idosa de alguma forma, tentando fazê-lo com gestos e palavras, gentilmente aceitos pela idosa. Porém, percebeu, também, que em determinados momentos era preciso silenciar até que as palavras e pensamentos fossem conscientizados. 
Ao final da entrevista, a idosa agradeceu muito e referiu ter sido de grande valia e muito prazeroso o encontro, pela disponibilidade e dedicação com que alguém havia se disposto a ouvi-la. Por meio da observação do cotidiano dessa idosa, percebeu-se que, a cada aproximação das pessoas, ela iniciava uma tentativa, frustrada na maioria das vezes, de contar detalhadamente sobre o marido e as filhas, sempre ceifada por pretextos de falta de tempo, ou por chavões do tipo "pois é, é assim mesmo", "não é nada, um dia elas aparecem".

A segunda entrevistada foi apresentada à pesquisa e seus propósitos quando, em uma conversa informal com a pesquisadora, questionou sobre seus estudos na USP, mostrando-se interessada. Foi, então, detalhada em que consistia sua participação e, por iniciativa própria, a idosa sugeriu horário e local onde pudesse ocorrer a entrevista.

No início da entrevista, a idosa demonstrou um maior interesse na sua participação do estudo do que nos propósitos da pesquisa em si, fazendo com que a pesquisadora criasse uma expectativa negativa em relação aos achados. No entanto, esta idosa iniciou um relato no qual havia experienciado, na juventude, o suicídio do namorado, e que nunca havia sido relatado. Ao final, pareceu à entrevistadora que o desejo inicial da idosa em participar da pesquisa era um reflexo da sua necessidade em reproduzir sua vivência a alguém, numa tentativa de confirmação da ausência de culpa.

O terceiro entrevistado cultivava uma relação de amizade com a maioria das pessoas da instituição, tanto companheiros como funcionários e cuidadores, porém, com evitação em relação a assuntos de foro íntimo. Quando convidado a participar da entrevista, aceitou prontamente, referindo ter "muita coisa a dizer". Pelo tom lúdico demonstrado, a entrevistadora manteve-se, a princípio, receosa sobre a fidedignidade da entrevista. Ao ser iniciada, o idoso citou prontamente a separação conjugal pela qual havia passado, referindo-se a ela como uma "coisa ruim", que "não merecia ser lembrada". No entanto, no decorrer da entrevista, foi relatado todo o processo de separação e seus sentimentos pela mulher antes, durante e após o término do casamento, deixando transparecer, espontaneamente, a veracidade dos mesmos. Esse idoso mostrou-se uma pessoa reservada, entretanto, contagiada pelo intuito da pesquisa e pela atmosfera produzida pelo encontro.

A quarta entrevistada não teve a mesma experiência. Queixando-se freqüentemente de solidão e incapacidade para realizar tarefas domésticas de baixa complexidade e até 
dificuldade para deambular, a oportunidade de participar da pesquisa foi aceita com excitação. Entretanto, manter o diálogo voltado ao propósito do trabalho não foi tarefa simples. A entrevistada, inicialmente, evitou relatar suas perdas, esquivando-se de perguntas diretas, cedendo apenas depois de se sentir segura e confortável com sua interlocutora.

A quinta pessoa entrevistada não possuía vínculos de amizade com outros companheiros de asilo. Aproximou-se da pesquisadora queixando-se de falta de companhia para manter diálogos e relações de amizade. Observando a carência afetiva e social daquela idosa, a entrevistadora convidou-a para participar da pesquisa, tendo sido o convite aceito igualmente com excitação.

Já no início, mostrou sinais de tristeza e choro fácil. Iniciou a entrevista falando sobre a mãe e a irmã, que haviam falecido; depois sobre a família, com quem sempre teve pouco contato. Contou a respeito da sua vinda ao asilo, de sua aposentadoria e de como se sentia em relação ao trabalho - e à falta dele. Sua fala era hesitante, entrecortada por períodos longos de silêncio, como se estivesse ponderando sobre abordar ou não um ou outro assunto.

Aparentando ter se decidido, falou sobre um amigo que tivera no asilo, e, mudando o modo de discursar, começou a contar com entusiasmo. Contou sobre o relacionamento e seu fim. Sentia-se só sem a presença deste homem, no qual depositava sentimentos de confiança e companheirismo. Aparentemente, essa foi a entrevista na qual a pesquisadora sentiu-se mais útil, pela perda recente ainda estar em processo de elaboração e pela necessidade de ajuda em fazê-lo, demonstrada pela idosa.

O sexto e último entrevistado era um senhor bem aparentado, que não permanecia muito tempo no asilo, pois costumava sair freqüentemente com os amigos para ir ao bar. Foi abordado logo cedo, antes de sair, e durante uma conversa informal, concordou em participar da pesquisa, insistindo para que a entrevista fosse em um dos bancos do jardim do asilo, mesmo tendo sido apontada a falta de privacidade do local.

A entrevista transcorreu com tranqüilidade. O idoso parecia não demonstrar dificuldade em relatar suas experiências anteriores, porém, em relação à separação conjugal, por vezes, demonstrou uma raiva intensa, e, até mesmo, embaraçamento, como se estivesse sentindo vergonha do que tinha acontecido. No entanto, ao final da conversa, fez 
referência a uma frase popular dizendo: "quem passou por essa vida e não sofreu, passou pela vida, não viveu", como uma tentativa de confortar a si mesmo.

Após a realização das entrevistas, as gravações foram transcritas na íntegra e seu conteúdo "lido e relido" profundamente para impregnar-se na pesquisadora, possibilitando a categorização e subcategorização dos dados para posterior análise. Os resultados foram agrupados em três categorias: perda por morte, perda por separação e outras perdas; sendo que a perda por separação foi dividida em outras três categorias: separação conjugal, separação da família e separação de companheiros da instituição, como visto a seguir. 


\section{RESULTADOS}

\subsection{Apresentação dos sujeitos}

Idoso 1. Herli (nome fictício), sexo feminino, 85 anos, dona de casa, viúva há nove anos, natural de Amparo-SP e procedente de Ribeirão Preto-SP, cinco filhos (uma mulher e quatro homens), com os quais tem muito pouco - ou quase nenhum - contato.

Refere, freqüentemente, queixas relacionadas à falta da família, do marido, dos netos, e um profundo sentimento de apreensão quanto ao modo desconhecido como a família está vivendo.

Residente na "enfermaria", devido a uma hérnia discal e sobrepeso, tem sobre a cama, sempre arrumada, um porta-retrato dos netos - já visivelmente judiado pelo tempo que diz ser "um presente para a filha" quando vier visitá-la. Passa a maior parte do tempo sentada ao lado da cama fazendo tricô para presentear os funcionários, sendo imprescindível a propaganda do seu trabalho manual a todos que passam.

$\mathrm{Na}$ maioria dos momentos de descontração, nas conversas com funcionários, médicos ou voluntários, refere a morte do marido e a ausência das filhas, sempre com choro fácil e, aparentemente, muita saudade, questionando-se com frequiência o porquê de Deus “ter tirado seu homem e não a levado junto". O marido havia sido seu primeiro namorado, vizinho da casa de seus pais na infância, cujas famílias eram fortemente unidas - inclusive, referia-se à sogra como sua "segunda mãe".

Fora morar no asilo, em 2001, por não querer viver com o filho etilista. Após a viuvez, uma de suas filhas, juntamente com o marido, havia lhe trazido para Ribeirão Preto com o propósito de visitar esse filho, distante, e a havia deixado aqui, com ele. Herli refere que não "suportava" ver o filho bebendo "sem parar" e que, apesar de ser seu filho, optou por sair de casa a tentar ajudá-lo. Antes de decidir pelo asilo, ocorreu-lhe que poderia tentar morar com outro filho, mas o relacionamento complicado com a nora fora seu impedimento. 
Idoso 2. Bela (nome fictício), sexo feminino, 76 anos, lavadeira e passadeira, desquitada, natural de São Paulo-SP e procedente de Ribeirão Preto-SP, três filhos (duas mulheres e um homem), fruto de um casamento "arranjado" pelo pai.

Havia tentado se desvencilhar do noivado diversas vezes, todas sem sucesso por medo da família. Após o casamento, o marido a tratava mal, escondia-lhe dinheiro e, freqüentemente, a traía, até ela expulsá-lo de casa, avisando à polícia que o mataria se voltasse. A partir de então, "chamou pra si" a responsabilidade de sustentar os filhos sozinha, trabalhando fora e fazendo hora extra.

Refere que seu desejo era ter fugido com o rapaz que amava na adolescência, mas, para não desobedecer aos pais, não o havia feito. Ele praticara suicídio por não poder tê-la, deixando duas cartas, uma para ela e outra para a irmã. Bela refere ter sido "por sua causa, mas não sua culpa". A carta dizia que "se eles não pudessem ser felizes aqui, o seriam após a morte".

Fora morar no asilo por vontade própria, por não querer "atrapalhar" o casamento dos filhos. Antes disso, morava com um filho, a nora e o neto, mas não estava "dando conta" de arrumar a casa e cuidar da criança. Quando os filhos souberam que ela iria mudar-se para o asilo, tentaram levá-la de volta para casa, sem sucesso. Já havia residido anteriormente na casa de outro filho, na cidade de São Paulo, mas não mantinha um bom relacionamento com a nora.

No asilo, moradora da ala feminina das residências há cinco anos, divide o quarto com uma colega tabagista, inapetente e sem hábitos saudáveis de higiene, mas "sente muita pena e procura ajudá-la como pode". Já morou com outras mulheres, devido aos companheiros de quarto serem variados periodicamente de acordo com a necessidade da instituição. Quis, inicialmente, morar com outra colega, com quem tem maior afinidade, o que não foi permitido.

Bela passa a maior parte do tempo no centro da cidade, a fazer compras e favores para as colegas - como comprar frutas, levar roupas para o conserto e pagar contas. Possui muitos amigos na vizinhança e no comércio, pois morava no mesmo bairro antes de ir para o asilo, de quem ganha roupas e produtos de uso pessoal. Refere não sentir "tanta" falta de casa pela presença constante de muitos amigos ao seu redor. 
Idoso 3. Walter (nome fictício), sexo masculino, 72 anos, mecânico e eletricista, desquitado, natural de Miguelópolis-SP e procedente de Ribeirão Preto-SP, três filhas, com as quais não mantém contato direto. Somente uma das filhas telefona freqüentemente em busca de notícias.

Havia vivenciado uma separação conjugal devido a uma traição, sendo que uma das filhas é fruto desse relacionamento extraconjugal da ex-esposa. Relata que essa mulher era seu verdadeiro amor, e que, após a separação, já no asilo, ainda sonhava com ela. Após o divórcio, apesar de manter vários casos com diversas mulheres, optou por não se casar novamente. Relata sentir falta da primeira companheira, que havia deixado para ficar com a ex-esposa, pois poderiam ter sido felizes juntos. Também relata sentir falta da ex-esposa, porém, "do que ela era, não do que ela se tornou".

Morador das residências há seis anos, na ala masculina, havia dividido o quarto anteriormente com um companheiro que falecera de câncer há três meses. Tratava-se de alguém por quem tinha preocupação e cuidado, considerando-o um irmão. Antes dele, havia morado com outro colega de asilo, cujas filhas foram buscá-lo - diz-se ter sido por motivos financeiros. Tempos depois, esse colega fugira de outro asilo onde a filha o havia levado, deixando Walter muito triste e preocupado.

Hoje, passa a maior parte do tempo lendo livros no quarto e tomando vinho. É tabagista crônico há mais de vinte anos, de dois maços de cigarro de filtro por dia, e faz tratamento medicamentoso para tosse.

Ao se mudar para Ribeirão Preto em busca de residência e trabalho, após a separação, fora morar com uma filha, em cuja residência sentia-se empregado do genro para quem trabalhava sem remuneração -, mudando-se, assim, para o asilo em véspera do Natal de 2002, fato frisado fortemente pelo idoso durante a entrevista. Outras duas filhas e dois irmãos moram em diferentes cidades da região, porém, refere insatisfação frente a possibilidade de morarem juntos.

Idoso 4. Flora (nome fictício), sexo feminino, 81 anos, dona de casa e dama de companhia, natural do Japão e procedente de Ribeirão Preto-SP, viúva, três filhos homens, dos quais um trabalhava na instituição asilar até seis meses atrás. 
Sua visita inicial ao asilo teve o intuito de prestar serviços voluntários. Porém, sendo viúva e morando com esse filho, decidira se mudar para o asilo por conveniência: pela proximidade ao filho e pela ajuda aos outros.

Antes dessa mudança, em 2003, vivia passando de tempos em tempos nas casas dos outros filhos, porém, "não se sentia à vontade por causa das noras", que não demonstravam preocupação com ela. Por vezes, presenciava discussões entre os filhos e as noras, o que causava-lhe certa culpa.

Moradora das residências, sem companheira de quarto, passa o tempo fazendo crochê, com materiais cedidos pelo asilo, que são colocados à venda no bazar para arrecadar fundos para a instituição. Atualmente, vem sentindo muita dificuldade, pois tem artrite e artrose que, mesmo com tratamento medicamentoso e fisioterapia, mostram uma piora. Também assiste à televisão, prepara alguma comida em casa e faz atividades domésticas com dificuldade.

Idoso 5. Júlia (nome fictício), sexo feminino, 74 anos, babá e doméstica aposentada, solteira, natural de Uberaba-MG e procedente de Ribeirão Preto-SP, sem filhos.

Sem conhecer o pai, aos sete anos de idade apenas, havia deixado a casa da mãe à procura de trabalho. Por vezes, voltava à casa da mãe a passeio, onde, no entanto, permanecia por pouco tempo.

Era a filha mais nova de três irmãos. A irmã era legítima, mas o irmão era filho da mãe com outro companheiro. Demonstrou nunca ter tido contato com a família, mesmo quando ainda morava com a mãe. Disse ter voltado a fazer contato com a família com o auxílio de uma jornalista voluntária do asilo - momento em que descobrira que a mãe já havia falecido. A irmã também falecera há quase um ano.

Fora morar no asilo há treze anos por estar aposentada, sem família, sem trabalho e sem moradia fixa. Contribui com a instituição desde sua entrada, com $50 \%$ da aposentadoria, referindo "não querer morar de graça". No início, trabalhava como ajudante na cozinha, na limpeza e na organização do lar, juntamente com as irmãs; hoje denomina-se fisicamente incapaz de realizar essas e outras atividades.

No asilo, mantinha um relacionamento de amizade com um companheiro, residente na ala masculina, que há algum tempo vinha distanciando-se dela. Passavam a maior parte 
do tempo juntos, sendo que ela prestava-lhe auxílio com a alimentação, os medicamentos e as atividades de vida diárias. Aos domingos, desfrutava da companhia da família dele, que julgava ser a sua própria. Hoje, relata sentir "muita falta de sua companhia e dos almoços em família”.

Também relata sentir falta do trabalho e de uma atividade prazerosa, e, que somente gostaria de morar com a família novamente, se fosse para trabalhar, ser independente e ter seu próprio "canto".

Idoso 6. Carlos (nome fictício), sexo masculino, 63 anos, natural de São Paulo-SP e procedente de Ribeirão Preto-SP, desquitado, três filhos homens, com os quais não tem contato há mais de vinte anos.

Havia passado por um processo legal de separação complicado, pois a ex-mulher entrara na justiça para reclamar do valor da pensão, com auxílio de um advogado, conhecido seu de colégio. Na ocasião, recebeu ajuda de um médico, amigo de infância, pois estava sofrendo muito com a separação, apresentando, por vezes, episódios de autoagressividade.

Fora em busca da instituição por indicação de um dos diretores após vê-lo dormindo na rua, no centro da cidade. Não tinha dinheiro nem residência fixa, pois havia deixado para a mulher e os filhos após a separação, vindo para Ribeirão Preto atrás de trabalho, sozinho, sem ao menos conhecer a cidade ou algum amigo. No início, morava em pensão e vivia de "bicos", depois, sem emprego, começou a "beber" e dormir na rua.

Hoje, morador do asilo há sete anos, considera seus amigos e suas famílias a sua própria. Passa a maior parte do tempo sentado nos bancos do jardim, sozinho ou com colegas. Vai aos bares da vizinhança freqüentemente e ingere bebida alcoólica de duas a três vezes por semana. Por vezes, "exagera" na quantidade de álcool ingerido. 


\section{DISCUSSÃO}

\subsection{Perda por morte}

Sabe-se que, inconscientemente, os seres humanos são imortais e por isso evitam pensar na morte, o que os leva a aceitar a morte do próximo, com o pensamento "ainda bem que não fui eu”. Assim, a morte está sempre longe deles. Porém, quando começam a adoecer ou quando envelhecem, são colocados em confronto com sua condição de ser mortal e finito (TEIXEIRA, 2002).

Assim, ainda segundo essa autora, não se pode ignorar que a velhice é a fase de maior proximidade com situações de morte e, portanto, a etapa da vida de permanente confronto com a própria finitude. Nela, a perspectiva de vida torna-se diminuída e, pela finitude encontrar-se mais palpável, surgem novas tarefas relacionadas à compreensão de si mesmo e do sentido da vida.

O depoimento mais marcante acerca da perda por morte foi, certamente, o de Herli, que perdera o marido com quem tinha sido casada por 58 anos. Ele havia sido seu primeiro namorado, colega de infância, vizinho da casa onde morava com os pais. Juntos tiveram cinco filhos.

Porque perdi meu marido, perdi tudo [...] Em janeiro, nove anos que ele foi. Eé uma saudade que eu tenho... Mas dói... Eu vou te falar uma verdade: se saudade matasse faz tempo que eu já tinha ido... Nossa Senhora! Saudade dura! Que nem o médico falou: "Saudade não mata, vó, mas judia". E eu aqui... [...] Era tudo que eu tinha... Ele era tudo que eu tinha... Deus levou embora tudo que eu tinha... Levou embora... [choro e silêncio] Não é fácil, não. [choro e silêncio] Casamento é assim: jogar com a sorte. Porque você não sabe o que é que vai acontecer. Mas graças a Deus, tivemos sorte, né, graças a Deus. Tenho que pedir pro Pai do céu muito obrigado de tudo, meu Pai. Muito obrigado por tudo, meu Pai. [choro] Só que eu não acho bom ter levado ele, meu Pai, e não levou eu. Por quê? [choro e silêncio] Podia ter me levado junto com ele, meu Pai... [choro e silêncio prolongado]. (HERLI, 85 anos)

Percebe-se que o choro ocorre com freqüência durante a entrevista. Bowlby (1993) explica que as lágrimas são prováveis sempre que uma viúva se recorda da pessoa perdida, ou fala sobre ela, podendo levar, às vezes, a soluços incontroláveis. Embora seja surpreendente, há muitas razões para se acreditar que essas lágrimas e soluços são uma 
tentativa de recuperar a pessoa perdida. Isso pode ser explicado pelo fato de que o choro é a maneira pela qual a criança atrai e recupera a mãe ausente, ou alguma outra pessoa que possa ajudá-la nessa recuperação. Assim, acredita-se que no pesar o choro ocorra, consciente ou inconscientemente, com esse mesmo objetivo.

A viuvez na velhice, por seguir o popular "ritmo natural da vida", não deve provocar tanto impacto no cônjuge quanto em casais mais jovens, mas não se pode negar que a sobreposição de perdas demanda um trabalho muito mais intenso por parte do(a) viúvo(a) a fim de elaborar o luto. Geralmente nessa fase, os filhos estão adultos e já compuseram suas próprias famílias, portanto, o impacto maior acaba voltando-se apenas para o cônjuge, que se vê sozinho pela primeira vez após muitos anos de casamento. Nessa situação específica, o suporte familiar é de enorme valia (BROMBERG et al., 1996).

Nesse caso, após a morte do marido, os filhos de Herli não quiseram mantê-la por perto e decidiram, sem questionar ou informar a mãe, levá-la para a casa de um irmão distante, que morava sozinho por ser etilista crônico, alegando que se tratava apenas de uma visita. Quando se viu sozinha na casa do filho etilista, disse ser insustentável aquela situação e foi à procura de outro lugar para morar, encontrando, assim, o Lar Padre Euclides.

A minha filha me traiu pra vir aqui. Ela falou: "Mãe, vamos pra casa do L., visitar o L.". Mas vi arrumar mala, mala, mala. Falei: "Pra que tanta coisa pra levar?". "Não mãe, pra mim não tem pressa pra voltar". Mas voltaram no mesmo dia. Pegaram o ônibus e se mandaram. Ainda agüentei um ano com meu filho. Ele bebe, bebe, é ruim, fala palavrão. Aí eu falei com uma vizinha: "Se eu tivesse um asilo baratinho que eu pudesse pagar, eu ia morar lá porque eu quero sair daqui da casa do meu filho, porque eu não agüento. Não posso ver isso aqui". "Então pode deixar, que eu vou arrumar pra senhora um lugarzinho bom, a senhora vai ver." E ela me arrumou aqui. E tô aqui até hoje. (HERLI, 85 anos)

O abandono familiar em situações de viuvez na velhice, segundo Bromberg et al. (1996), não deveria ocorrer devido à situação fragilizada do viúvo, porém, a qualidade da relação conjugal que marcou o casamento deveria ser mais crucial que o apoio familiar para a resolução do processo de luto. Nesse caso, a principal impressão é que, apesar de o vínculo com o marido ter sido do tipo saudável, o abandono por parte dos filhos foi determinante para a manutenção do sentimento de luto, mesmo após muito tempo após a ocorrência da morte. 
É útil também ressaltar que o tempo de luto é variável, podendo perdurar por anos, em alguns casos. Em outros casos, pode-se dizer que o processo de luto nunca chega ao fim. Com o passar do tempo, surgem uma profunda tristeza, um desespero e um desânimo, que tomam conta do indivíduo quando este recorda a pessoa perdida. O traço mais permanente no luto é o sentimento de solidão.

Bowlby (1993) afirma que uma minoria substancial de viúvas nunca chega a recuperar totalmente seu estado inicial de saúde e bem-estar, e que um retorno ocasional do sofrimento ativo é comum - especialmente quando algum evento lembra a pessoa enlutada de sua perda. Talvez esse sentimento percebido no relato possa ser atribuído ao fato de que a morte do marido foi, primariamente, o fator desencadeante para sua entrada no asilo, momento em que se viu sozinha, sem companheiro e abandonada também pelos filhos. Portanto, se essa morte não tivesse ocorrido, poderia ter sido evitada, conseqüentemente, a institucionalização.

Diferentemente, mostram-se os relatos de Flora, que já havia perdido o marido tempos antes da institucionalização e recorda-se dele com alegria. Nesse caso, quando o marido morreu, Flora foi amparada pelos filhos, indo inclusive morar com eles antes de ir para a instituição. Porém, decidiu se mudar para o Lar pois não se sentia à vontade na casa das noras.

[...] Nora nunca gostou da sogra e sogra também cara feia não gosta. Quer dizer que não gosta, né?! Então, aí eu pensei assim: morar com meu filho, filho e mãe discutem mas daqui meia hora já tá tudo bem. Mas agora briga com nora nunca tá bem mais, nem eu nem ela, né?! Então, por causa de mim, marido e mulher brigam, e eu que eu tô estorvando?! Então eu pensei já que é assim, então eu vou pra um lugar melhor. (FLORA, 81 anos)

Ainda em relação à perda por morte, é igualmente interessante o relato de Bela, que perdeu o namorado por suicídio. Seu pai era contrário ao relacionamento e ela estava de casamento marcado, com um pretendente arranjado pelos pais, quando descobriu sobre a morte do namorado, a qual presenciou.

Humm... tem uma pessoa que eu gostei muito, e ele morreu... Se matou por causa de mim. Ah, não gosto nem de lembrar, minha filha... Eu queria casar com ele, meu pai não deixou. Aí ele chegou pra mim e me chamou pra fugir. Mas só que eu tinha medo do meu pai. Meu pai era bravo, eu tinha medo. [...] O dia que meu pai me pegou conversando com 
ele, ele quase me mata de uma pisa. Mas me bateu tanto, me bateu. [...] Ele falou assim: "Você vai lá na minha irmã que minha irmã tem um recado pra você". Aí eu fui, né?! Ela tava lá com um bilhete pra me dar. E deixou outro pra mim, pra dar pra ela. Só que não falava nada assim. Falava pra ir em tal lugar pra nós encontrarmos com ele. Ele pegou formicida Tatu e o cavalo, a hora que nós chegamos ele virou o copo. Se eu soubesse, não tinha deixado ele fazer isso, né, filha?! Tem tanto meio de viver sem fazer isso, né?! A única coisa que eu sinto saudade é dele. [...] Eu vi ele morrendo! Ele bebeu o veneno. [...] Ele virando o copo assim, um pedaço pra gente chegar, ele virou o copo. Eu e a irmã dele chegando. Depois tivemos que chamar a polícia, né?! Mostramos o bilhete que ele deixou pra polícia ver, tudo. Aí eu contei que eu namorava ele, que ele se matou por causa de mim, é verdade, mas eu não tive culpa, né?! Eu não tive culpa de nada... Sabe o que ele falou, antes de morrer?! No bilhete ele deixou assim: "Nós não somos felizes aqui mas o dia que nós morrermos, nós vamos se encontrar lá em cima". Ele falou pra mim... [silêncio prolongado] Tadinho... Ele era tão bom, menina... Mas bom mesmo... (BELA, 76 anos)

O que prevalece em casos de suicídio, segundo Parkes (1998), é a combinação de morte repentina, inesperada, horrível e precoce, com toda a raiva que a segue, mais a ocorrência do processo legal que podem gerar problemas psicológicos duradouros, como a culpa por ter falhado em proteger o morto. Os enlutados por suicídio tendem a sentir-se mais culpados e a ficar pensando o que mais poderiam ter feito, mas raramente este caracteriza um grande problema.

Mesmo não havendo dúvida de que uma morte súbita, inesperada, desencadeia um choque inicial muito maior do que a morte prevista, em geral, os pais de suicidas sofrem mais do que o marido ou a mulher, que tendem a ficar mais deprimidos, porém, recuperamse mais depressa. Bela demonstra muito pesar ao falar sobre o namorado perdido, porém demonstra um maior sentimento de raiva ao falar sobre o ex-marido, escolhido pelos pais, e sobre o casamento sem sucesso, como veremos adiante.

Walter e Júlia, outros dois entrevistados, também relataram que sentiram muito a perda da mãe, mas, também por ser entendida popularmente como "de curso normal" e que seja presenciada pelos filhos, não tendo sido demonstrado pesar. No entanto, há de se considerar as circunstâncias em que essas mortes ocorreram. No caso de Walter, eles não moravam juntos, mas tinham uma relação mãe-filho saudável; já no de Júlia, esta havia deixado a casa da mãe muito precocemente, aos sete anos, com o objetivo de procurar emprego e ganhar seu próprio dinheiro, e só ficou sabendo da morte da mãe muitos anos depois, já no asilo. 
Não sinto falta de família, não. A família que eu sentia falta era minha mãe, mas ela já morreu... O meu pai também. Agora minha família sou eu. (WALTER, 72 anos)

Não. Não tinha contato nem com a minha mãe [quando morava com ela]. Depois que eu vim aqui pro asilo que minha mãe faleceu, [...] Aconteceu muita coisa... Depois que eu vim pra cá. [silêncio] Saí de casa pra me virar... Ganhar meu dinheirinho... E vai saindo, vai sumindo. Eu voltei lá, mas não fiquei lá com ela não, continuei andando, trabalhando. [...] É... [silêncio] Eu tenho fotografia dela aí... Da minha mãe... Ela faleceu depois que eu vim pra cá... [silêncio prolongado] Foi muito ruim... [choro e silêncio prolongado] (JÚLIA, 74 anos)

Esses achados corroboram os relatos científicos no que diz respeito à qualidade do vínculo existido anteriormente e o enfrentamento do processo de luto. No caso de um vínculo ansioso, como o de Júlia com sua mãe, há uma dificuldade no estabelecimento da auto-estima e autoconfiança, tendendo o indivíduo a sentir-se isolado e solitário e mais suscetível a desenvolver quadros psicossomáticos (BROMBERG et al., 1996).

Parkes (1995), em seu estudo com filhos adultos enlutados, relata que, das 22 mulheres e cinco homens que foram indicados a tratamento psiquiátrico após a morte de um dos pais, um terço deles não havia se casado e, dos que haviam, apenas um mantinha um casamento satisfatório. Também, 70\% apresentavam baixa autoconfiança e, sem uma relação conjugal solidária, demonstraram muita dificuldade em enfrentar a morte.

Júlia informou que nunca havia se casado, e que, somente no asilo, encontrara um companheiro verdadeiro. Porém, conta também que nos últimos meses esse companheiro a vem destratando e que ela se sente muito triste e sozinha por isso, que será discutido adiante. Também relata com pesar a perda da irmã mais velha, única pessoa com quem tinha contato na infância e cuja filha a tinha encontrado no asilo, muito tempo após ter abandonado a família.

A minha irmã mais velha conheceu o pai. Nós duas somos filhas de um pai só, de um casamento da minha mãe. Só que o meu irmão era filho do padrasto. Ele já morreu também. Minha irmã faleceu... Me deu "depressão" por causa da morte dela... Até emagreci... Eu emagreci muito por causa desse negócio... Eu não tava comendo, não tava bebendo, não podia sentir cheiro de comida... [choro e silêncio] Ela morreu me chamando, sabe?! Eu fiquei muito sentida... Chorei muito... [silêncio prolongado] Olha, eles passaram quarenta anos me procurando. Agora em outubro, novembro vai fazer um ano que eles me acharam. Minha sobrinha de São Paulo é que me achou. Ela ligou em todos os asilos me procurando. "Preciso achar a tia". Nem as crianças eu conhecia... Já pensou?!... [choro e silêncio prolongado] Quarenta anos sem ter contato. Essa minha sobrinha eu nunca tinha 
visto ela. Nem de criança eu tinha conhecido ela. Agora, depois de velha, é que eu fiquei conhecendo... Ainda faltam mais três que eu não conheço... (JÚLIA, 74 anos)

Outra perda importante por morte foi relatada por Walter, cujo companheiro de quarto morrera de câncer. As relações interpessoais entre colegas de asilamento são de extrema importância, pois, como dito anteriormente, contribuem para a adaptação do idoso na instituição e, conseqüentemente, para a vida em comunidade, já que na velhice essa capacidade de adaptar-se a mudanças encontra-se prejudicada. É possível que vínculos sejam formados, e rompidos, a partir dessas relações.

Só não tenho sorte com parceiro. Olha aí, puseram um parceiro, tava bom. Ninguém queria ele, puseram ele aí. Durou pouco, morreu, coitado. Era o J. O J. tava tomando remédio pro intestino, ele tinha câncer. Ele ia no banheiro, ia no banheiro, e chorava. Ele levantava de madrugada e ia. Eu falava: "Por que você não toma banho aí? O banheiro tá aí. É só nosso o banheiro. Do lado de lá não mora ninguém. O banheiro é nosso, o guarda-roupa é nosso. Toalha tem até demais aí, tá até sobrando. Tem roupa aî". Não. Ele levantava cinco horas da manhã, ia lá. Ele não esperava nem o P., ele ia cedo. Ia e voltava correndo e cama. Ia lá, tomava o café, voltava e cama. E ia assim. De noite, ele levantava e ficava, a luz apagada mas entrava um claro daqui [janela], acendia a luz e falava: "Nossa, mas ainda é essa hora?!", apagava a luz e tornava a deitar. Eu falava: "J., pode deitar, a hora de tomar banho eu te chamo". Eu durmo, mas de um olho só, o outro fica acordado... Coitado... Tava bom com ele... (WALTER, 72 anos)

\subsection{Perda por separação}

\subsubsection{Separação conjugal}

A separação conjugal é uma das experiências mais dolorosas ao ser humano, um outro tipo de morte vivenciada, inevitavelmente, por todos. Para Caruso (1982), estudar a separação amorosa é estudar a presença da morte em nossa vida. Por ser uma capitulação diante da morte, ela pode ser, muitas vezes, mais sofrida do que a própria morte.

Segundo Berthoud; Bromberg; Coelho (1992), a separação, que traz o sentimento de "nunca mais", assim como na morte, mas sem morte concreta, desencadeia outros sintomas, como: 
- Catástrofe do ego: a separação produz uma morte na consciência e daí o desespero. Há uma mutilação egóica, a identidade sucumbe, acionando mecanismos de defesa para que esta morte não aniquile a consciência e não leve ao suicídio.

- Agressividade: pode surgir como mecanismo de defesa, em direção àquele que abandonou. A desvalorização do ausente é uma forma de tentar reconciliar o ego ferido com o ideal abalado. Assim, o amor pode se transformar em ódio, facilitando o desligamento do objeto.

- Indiferença: há uma diminuição forçada da idealização egóica. Pode-se arriscar uma analogia com a rigidez da morte, uma renúncia ao prazer para se evitar o desprazer.

- Fuga para adiante: busca de novas atividades ou de novas formas de prazer em substituição à pessoa perdida. $\mathrm{O}$ ego sofredor necessita de consolo.

- Idealização: rebelião contra o processo de morte na iminência de se instalar.

Três dos seis idosos, dois homens e uma mulher, relataram suas vivências de separação, sendo que todas elas referiram-se a episódios potencialmente traumáticos em suas vidas, tanto pela qualidade do vínculo com o cônjuge como pelo processo de separação em si. Desses três, dois (um homem e uma mulher) experienciaram uma traição amorosa.

São facilmente perceptíveis os sentimentos de raiva e ressentimento que Bela demonstra ao relatar os motivos da sua separação conjugal:

Me arrumou um casamento que... Eu ajoelhei no pé do meu pai, filha, ajoelhei! Ele pedia pra eu casar, eu pedia: "Pai, eu não quero casar com ele, eu não quero!". "Se você não casar, você morre". Eu tinha medo, né, filha?! Eu não queria, filha, de jeito nenhum! Não gostava dele! Ruim assim pra me judiar, não era, mas só vivia atrás de mulher... Um dia peguei a calça dele toda cheia de sangue!!! Quê?! Viver com um traste desse?! Eu queria largar dele desde o primeiro filho!!! Meu pai não deixou: "Não vai sujar a família, na família não tem nada disso, não sei o quê". Fui relevando, relevando... No fim eu não agüentei! (BELA, 76 anos)

Bowlby (1993) ressalta que a raiva é habitual e útil quando a separação é apenas temporária. Quando há permanência, esta é deslocada. Assim, a raiva é vista como um componente, mesmo que por vezes desorientador, do esforço realizado pela pessoa enlutada, que surge esporadicamente na tentativa de restabelecer o objeto perdido. Entretanto, quando há persistência dos sentimentos de raiva e ressentimento após as 
primeiras semanas de luto, há razões para preocupação, pois, junto com esses sentimentos, há a probabilidade de existir uma tristeza profunda e generalizada.

No caso de Bela, para analisar a permanência dos sentimentos de raiva e ressentimento, é igualmente necessário considerar a qualidade da relação e a presença ou não do vínculo com o cônjuge. Ela havia sido obrigada a se casar com uma pessoa que não gostava, por imposição do pai, após ter vivenciado o suicídio do homem que realmente amava, além de ter sofrido com diversas traições do marido. Essa tristeza profunda, que coexiste com o sentimento de raiva, pode ter surgido a partir do episódio anterior de perda (do namorado), que ocorrera acompanhado pelo sentimento de culpa. Atualmente, há evidências de que circunstâncias sociais e psicológicas que ocorreram ao enlutado durante o ano que se segue à perda, aproximadamente, podem influenciar consideravelmente o processo de luto.

Segundo Kovács (1992), a culpa e a ambivalência são processos patogênicos que podem tornar o luto complicado, havendo alternância entre os sentimentos de amor e ódio. $\mathrm{O}$ ódio atua tirando prazer dos sofrimentos pelas degradações e passa a atuar internamente como uma autopunição. É uma vingança contra o objeto perdido, muito comum nos processos de separação.

Era fogo, minha filha, ele era fogo... Sabe onde eu achei dinheiro que ele escondia?! Sabe a caixa da descarga do banheiro?! Sabe aquele saco de arroz que é grosso?! Tinha um saco cheio de dinheiro que ele pôs dentro da descarga pra eu não achar... Acredita?! [...] E depois que eu separei do meu marido, ele aprontou uma boa comigo... Ele não quis roubar meu filho??? É!!! Ele queria pegar o moleque pra ele depois de nove anos, acha que ia dar?! Eu peguei e fui atrás de ir buscar ele. Peguei ele, ele tava chorando. Quando ele me viu ele chorou, tadinho. [...] Ele me judiou até o fim, minha filha. E também, pra se livrar, perante Deus, filha, eu prometo até pra Jesus, ele andou falando pra todo mundo que ele largou de mim porque eu tinha um amigado, sendo que eu que larguei dele, que não deixei ele entrar. Até isso ele levantou calúnia de mim, pra livrar a barra dele, né?! Eu que mandei ele embora, falei: "aqui você não entra mais". [...] Eu pus a polícia pra pegar a roupa dele. Falei pro delegado assim: "Se ele apontar na porta, eu puxo o gatilho". Falei! Eu não tinha revólver. "Eu acabo com a vida dele. Ou ele acaba com a minha ou eu acabo com a dele! [...] Eu falei: "A roupa dele ta lá, olha. O senhor já leva e não manda ele aparecer aqui". Sabe o que ele fazia?! Ele pegava a amigada e passava perto de mim pra lá e pra cá assim... Ih, ele é triste, minha filha. Eu sofri com ele... Depois que nós separamos, ele ainda me judiou, ainda. Mas, do resto, eu sou feliz em tudo, graças à Deus. (BELA, 76 anos) 
É igualmente perceptível a necessidade de Bela em contar, com detalhes, como o marido a tratava e tudo o que fazia para prejudicá-la, antes e depois da separação, na aparente tentativa de justificar seu feito. Assim também ocorreu no relato de Carlos e Walter, os outros dois idosos marcados pela separação conjugal. Essa atitude pode ser relacionada com a agressividade que Berthoud; Bromberg; Coelho (1998) afirmam desenvolver-se com a separação, e que, pela qual, a desvalorização do ausente faz com que o amor se transforme em ódio mais facilmente, favorecendo o desligamento do objeto.

É. Foi mais ou menos assim, enquanto eu tinha dinheiro, eu levava ela pro Rio, pra todo lado, tinha carro, dois carros por ano, zero quilômetro... Ora, era três, quatro vezes de viagem pro Rio de Janeiro, ficava uma semana... Ela ficava com saudade dos pais dela, porque ela era carioca. Eu falava: "Vamos, né?!”. Arrumava as mala e tá pronto! Ficava uma semana lá. Cada semana um pacote. Cada viagem um pacote. "Ah, vou fazer compra em Madureira...". "Vai lá na bolsa, lá, pega o que você precisa e compra”... Aío negócio foi "coisando", e por que faltou dinheiro pra distinta, eu falei: "Vamos regular um pouquinho?”. Depois eu falei: "Quer saber de uma coisa?! Eu vou atrás do meu!". Aí, o barco virou, como dizia, pegou fogo em Roma e eu perdi tudo. É um negócio... Foi apertando o negócio com ela, fui relaxando, relaxando... Eu falei: "toma! Você queria meu dinheiro, então toma!". Aí, eu já estava em Poços de Caldas, já tinha saído de casa e ido pra Poços de Caldas... Não dei confiança... Daí uns dois meses ela arrumou um advogado que queria separar de mim. Queria pegar o [gesto de dinheiro]. Inclusive o advogado era conhecido meu de colégio! Aí mandou falar: "Eu quero o seguinte: a casa”, e a casa tinha apartamento em cima. Casa de $2870 \mathrm{~m}^{2}$. É um quarteirão quase. Eu falei: "Tá aqui, repartido. A metade é dela. A outra metade, quando vender, eu não quero nem um tostão. Mas é o seguinte", naquele tempo, vendeu, dava três mil "reais", era dinheiro à beça, né?! "Três mil pro M., três mil pro R., e três mil pro R., na poupança. Nem eu, nem ela, nem o sogro, ninguém pode tirar. Só depois de dezoito anos." Dinheiro vivo. Depois a última vez que eu fui lá, ela foi reclamar da pensão pro juiz, eu falei: "Larga a mão disso que é perigoso você ter que dar pensão pra mim!". (CARLOS, 63 anos)

Tem a M., mora lá também. Mas essa eu não me dou com ela. Não me dou com ela, não, ela não é minha filha, você entende?! É minha filha no papel, mas, você acha que você não sabe qual é o biscoito que vocêfez e o que você não fez?! Ara! Não, não é! A M. não é minha, por isso que eu sou separado... Só por isso... Você acha que eu vou criar cabra, pros outros mamar em mim?! Pode?! Trabalhava feito um louco! Ah, não! Olha, eu trabalhava em Uberaba! Eu era tão bom que ela trabalhava de empregada, antes de casar eu tirei ela do emprego, deixei ela na casa dela, eu pagava mais pra ela ficar com a mãe dela do que pra ela ir trabalhar. E adiantou??? Ah, antes de casar era uma beleza... Depois, menina, o trem virou!!! Foi onde eu separei, né?! "Agora, não!”. Separei! Larguei pra lá e vim embora pra cá. Vim pra casa da minha mãe. A minha sogra veio atrás de mim: "Você ainda é novo, não sei o quê". Falei: "Não, não, não, não...". [silêncio] E a separação deixa pra lá que eu prefiro nem lembrar. Eu gosto de lembrar de coisa boa. [silêncio prolongado] [...] E você sabe que eu nunca gostei mais de nenhuma mulher a não ser daquela?! Gostava no duro! Eu casei com ela porque eu gostava dela, 
não porque ele era bonita, não era rica, nada... Cheguei a sonhar muito com ela, mas parou. Agora parou. (WALTER, 72 anos)

No caso de Walter, é também possível fazer referência ao profundo e persistente sentimento de solidão sofrido pela pessoa enlutada. A solidão emocional só pode ser remediada pelo envolvimento em uma relação de dedicação, sem a qual não haja sentimento de segurança. Essas relações potencialmente de longo prazo são diferentes das amizades comuns e, nas sociedades ocidentais, ocorrem apenas de algumas maneiras: através do casamento ou por outras relações que envolvem compromisso sexual; entre as mulheres, pelas relações com uma amiga íntima, uma irmã ou a mãe; e entre os homens, pelas relações com alguns colegas (WEISS, 1975).

É notadamente visível que Walter cultivava esse sentimento de solidão desde imediatamente após a separação, quando mudou de cidade, afastando-se da família (que será discutido posteriormente), até no asilo, onde passava a maior parte do tempo lendo, sozinho, no quarto.

Carlos também relata ter vivenciado a solidão ao término do casamento, tendo, inclusive, se afastado dos três filhos até hoje. Ele não os vê há mais de vinte anos. A raiva também é observada em outro momento da entrevista, como se vê a seguir.

Tanto aqui como lá fora, né?! Hoje tenho muita amizade! É pra ter, né?! Porque do jeito que tá a vida, não ter amigo, você vai ficar sozinho?! Ficar sozinho é triste... [...] Envelheci antes da hora... Fiquei de cabelo branco... E chorava, chorava como criança, sozinho, pra ninguém ver... É... [silêncio] Mas agora os garotos estão bem... Faz mais de vinte anos que eu não tenho notícia... Eles sabem que eu tô aqui em Ribeirão, mas também eu não procuro... Ora, eu deixei tudo lá! Pra bem dizer, eu vim com uma mão pra frente e outra pra trás! Isso me dá um estado de nervo! Não é arrependimento... Eu deixei por causa dos garotos, mas se fosse por causa dela, não ia deixar nem um tostão... (CARLOS, 63 anos)

Uma vez eu saí. Fui pra Poços de Caldas. Eu quebrei até esse braço aqui. Eu chorava, mas eu chorava. Dava murro, quebrei o osso assim. De raiva. Depois o médico me botou na cabeça pra eu deixar de ser burro... Eu tava explicando pra ele, tava conversando uma noite. E ele me botou na cabeça: "Deixa de ser bobo!". E eu falei: "Você sabe?! Eu acho que eu sou bobo mesmo, viu?!". Olha aqui! Eu quebrei mesmo! Eu falei: "O que é isso?! Você vai descontar na árvore?! O que a árvore tem a ver com o teu problema?! É. Mas é pra relaxar!". Aí, eu falei pra ele: "Ô doutor, você disse que homem não chora, mas eu fui chorar longe pra ninguém ver e dava murro de raiva"... Eu digo assim, que nem dizia o médico: "Passou isso, passou aquilo. Agora pega essa borracha e apaga tudo o que você passou e vai começar a escrever daqui pra frente. Esquece!". O defeito da pessoa é ficar parado. Não pode ficar parado assim, de "nhenhenhe"... Tem um 
ditado antigo: Água parada cria bicho. Porque ficar relembrando certas coisas vai te dando revolta... Então, esquece... (CARLOS, 63 anos).

Silva et al. (2006) afirmam que o idoso, ao se perceber sozinho no asilo queixa-se freqüentemente de solidão, entretanto, alguns se recusam a interagir com seus companheiros de asilamento. Contudo, com o estímulo à interação realizado pelos cuidadores, percebe-se a formação de novos vínculos afetivos o decorrer do tempo de asilamento, surgindo entre eles uma amizade, um sentimento de solidariedade mútua, de compartilhamento das ansiedades, preocupações e perdas.

Sendo assim, a amizade como relacionamento de harmonia, onde dois idosos se apóiam e preocupam-se um com o outro mutuamente, pode ser considerado um fator propiciador de um ambiente saudável para todos os residentes de instituições asilares (SILVA et al., 2006).

\subsubsection{Separação da família}

Em se tratando de idosos institucionalizados, todos os entrevistados relataram separação da família, porém, o que devemos valorizar é se essa separação ocorreu antes do asilamento ou como causa/conseqüência dele. Mesmo a maioria dos idosos dizendo que foi para o asilo por vontade própria, quando analisadas as histórias de vida de cada um, percebe-se que há um abandono real por parte da família para que essa decisão tenha sido tomada.

Herli, por exemplo, inicia seu relato afirmando que morava no asilo porque queria, mas, no decorrer da entrevista, diz que a filha a enganara para trazê-la para Ribeirão Preto como já visto anteriormente - e que não queria dar trabalho para os filhos. Berthoud; Bromberg; Coelho (1998) discutem o significado da fala da maioria dos idosos que abomina a idéia de um dia depender dos filhos, sendo que estes já dependeram dos pais num determinado tempo da vida.

Eu tô aqui porque eu quis, entende? Eu não quis morar com meus filhos porque do jeito que eu tô eu vou dar trabalho pra um, vou dar trabalho pro outro, então eu não quis. Ou eu sou gente ou eu sou objeto, entende?! Ainda mais nora! Quatro noras! Você acha 
que eu ia agüentar morar com nora??? [risadas] Mas eu sinto falta... Da minha filha, da minha gente, falta dos filhos, meu marido... [silêncio] Que nem, agora, não sei da minha filha, se tá viva, se tá morta, sei lá. Desde o Natal não tenho notícia dela... Ih, queria saber meu Deus... Nem que fosse um telefonema que desse: "Só pra saber, mãe, tá tudo bem, mãe?". Ninguém telefona... [silêncio] Era uma família maravilhosa, uma família, minha sogra, você tinha que ver que coisa linda, ela tinha onze filhos. Onze! Não era um nem dois, onze! Oito homens. Moço, tudo moço já. E nós vivíamos numa maravilha, sentava na mesa, conversava, brincava. Era uma coisa linda, coisa bonita pra danar, meu Deus do céu. Falei, puxa vida! Mas você tem que ver que maravilha era lá. Era uma família mesmo! (HERLI, 85 anos)

Segundo Berthoud; Bromberg; Coelho (1998), o idoso não quer ser um peso, uma carga, então, ele aceita bem o fato de abandonar a família e ir morar na instituição, como o índio ancião, em muitas culturas, que aceita ir para a floresta para esperar a morte chegar quando não tem mais funcionalidade para a tribo. Assim é o asilo. No momento em que se dá o asilamento, o abandono é clarificado e as perdas de toda uma vida são concretizadas na chegada à instituição. Somado a isso, ocorre o último rompimento: o mundo lá fora está perdido para sempre. É o isolamento causado pelo asilamento.

Até mesmo na fala de Bela, que afirma precisamente ter-se mudado para o asilo por vontade própria, percebem-se sinais de um abandono familiar, assim como na de Walter, que se distanciou da família com a separação conjugal, antes de ter entrado na instituição, porém, mesmo depois manteve o distanciamento. Nessa última também se nota a negação do idoso de depender dos familiares.

Vim escondida, porque se eu falasse que eu vinha pra cá, eles não deixavam. Quiseram me tirar. Eu acho que, pelo menos aqui, eu tenho uma liberdade, entendeu?! Na casa de nora, pode ser bom, mas a gente não tem liberdade. Não tem, filha, entendeu?! "Ah, filha, eu tô cansada, vou procurar um jeito pra mim". "A mãe que sabe, a mãe já olhou bastante meus filhos. Eu fico em casa e olho eles". Aí a irmã dela não foi mais trabalhar, sabe, ela ficou olhando eles. Eu tava cansada. (BELA, 76 anos)

Depois vim pra cá, daí comecei a trabalhar em sítio, por aí, fazendo cerca. Fui pra Santa Rosa do Viterbo, São Simão, fui pra Santo Antonio da Alegria, Santa Cruz da Esperança, voltei pra Santa Rosa outra vez, depois de lá eu vim pra cá, pra Ribeirão, e fui morar com uma irmã, ali na Quinta da Alvorada. Aí, foi a pior viagem! [risos] Porque eu não fui morar com a minha irmã, fui ser empregado do meu cunhado, você calcula. Eu só fazia comida pra cachorro, podava o jardim e não ganhava "niente". Vivia com o dinheiro do fundo de garantia que eu recebia. Depois lá, um dia, cismei, cismaram de pôr eu aqui, pôs. Eu vim pra cá. Puseram eu aqui. Não vou mais lá, não! Eu vim pra cá numa véspera de Natal... Faz cinco anos, vai pra seis anos já. Vê só cada parente! Eu vim pra cá na véspera de Natal, olha... Passei o Natal aqui. O primeiro Natal foi aqui dentro... [...] Olha, 
a gente quando vai na casa de um parente, os dois, três primeiros dias é bom, depois já não... a não ser que você tenha emprego. Se você vai trabalhar, fica fora o dia inteiro, só vem em casa à noite. Aí, não, né?! Mas, eu tenho cunhado, ele vai trabalhar, ele não vai ficar lá fazendo sala pra mim. Não... Não dá, não... A hora que eu quero deitar, eu venho aqui e deito, aqui ninguém me amola. (WALTER, 72 anos)

Assim também se desenvolve a fala de Flora, que, quando ficou viúva, tentou morar com os filhos e as noras mas não se sentiu à vontade, e que relatou a ida ao asilo como uma decisão tomada em conjunto com o filho. Porém, percebe-se, não só por esta mas pelas falas anteriores, que Flora sentia-se abandonada mesmo estando na companhia dos filhos e noras e que a ida no asilo foi escolhida como uma busca pela aceitação.

Aqui é melhor. Porque se eu quero dormir, eu durmo. Se quer assistir televisão, assiste, se não quer, apaga, vai dormir... Quer levantar, a gente levanta... Então, eu falo assim: "Pra mim o melhor lugar é aqui". Dia vinte de maio eu completei 81 e o tempo melhor que eu vivi, acho que é aqui... Porque um é bom, outro é melhor, aqui a gente conversa, já tá velha mesmo... [...] Porque ninguém xinga, ninguém faz cara feia. Aquilo não pode mexer, aquilo não pode comer, pra aquilo não tem dinheiro, eu falo: "Não, porque eu quero, eu compro, né?!". Porque se eu quero, tenho vontade de comer, mando comprar, né?! [...] Não sei se elas não gostam de mim... Elas nunca falaram: "A janta tá pronta, vai jantar". Nunca falou: "Aí na geladeira tem maionese, se a senhora quiser, a senhora tira", nunca falou. Então, meu filho que ia e pegava: "Toma, mãe". Aí eu pegava um pouquinho... Era sempre assim... Então... [choro e silêncio] Eu acho que, eu se eu comprasse, eu mandava fazer pra todo mundo... [silêncio prolongado] É... O que eu passei... Acho que eu não quero passar outra vez, não... Aqui é muito melhor. Ninguém fica brigando. Quem gosta de mim, gosta, não vou lá pedir pra gostar de mim... (FLORA, 81 anos)

No entanto, outra idosa, Júlia, relata que abandonou a casa da mãe muito precocemente, tendo, portanto, ocorrido a separação familiar tempos antes do asilamento. Percebe-se, também, em sua fala, que há sinais de arrependimento parcial desse abandono familiar precoce principalmente por ter sido no asilo que ficara sabendo sobre a morte da mãe e da irmã, como se houvesse um sentimento de culpa, como já demonstrado anteriormente.

Eu com sete anos saía de casa pra trabalhar, me virar... Subia num caixotinho pra fazer comida... [silêncio] [...] Eu tinha sete anos quando eu saí. Comecei a me virar, trabalhar, a ganhar meu dinheirinho... Até pouco tempo eu ainda tava trabalhando, de empregada, ganhando meu dinheiro. Depois eu aposentei e vim pra cá... [...] Ah, a gente acostuma, né?! A gente nunca vive com a família muito tempo. A família sai, vai esparramando, vai pra um lado, vai pro outro... (JÚLIA, 74 anos) 
Morava com meus filhos... Até separar... Mas faz mais de 22 anos que eu não vejo, não converso mais com eles. Eu digo, eu sou um passarinho, sou um passarinho voando... [...] Eu vim pra cá trabalhar, a firma faliu... Fiquei quase dois anos morando debaixo de marquise, lá na Mariana Junqueira, aí depois consegui vir pra cá. Foi em 2000. Faz sete anos que eu tô aqui. Vim sozinho... (CARLOS, 63 anos)

Portanto, a separação familiar como causa da institucionalização foi relatada por quatro dos seis idosos entrevistados. Nos outros dois, o abandono havia sido por parte do idoso em relação à família e havia ocorrido consideravelmente antes do asilamento, porém, um deles relacionou o abandono também como consequiência da institucionalização, juntamente com outros dois do primeiro grupo citado - que considerava a separação como causa do asilamento.

\subsubsection{Separação de companheiros da instituição}

A separação de companheiros da instituição foi relatada por dois idosos, Walter e Júlia, sendo que, no primeiro relato, a separação ocorreu porque a família de seu companheiro de quarto fora ao asilo e o retirara forçadamente de lá. Como ele era portador de doença mental, ninguém pode impedir a família de fazê-lo. Muitos comentavam que havia sido por motivo de dinheiro. Já no segundo caso, a separação ocorreu por afastamento do companheiro, sem motivo declarado.

Não tenho sorte com parceiro. Morei com o J. [que morrera de câncer], depois morei com o A. um tempo. Aquele seu A., das mulheres, lembra dele?! Veio um recado que se ele aparecesse por aqui era pra comunicar eles lá. Ele fugiu de lá. Fugiu!!! Olha as filhas dele!!! Levaram o homem daqui, puseram num asilo que tem lá. Vai ver que não era que nem aqui, o homem foi embora mesmo. Aqui a gente tem tudo... (WALTER, 72 anos)

Gosto daqui, gosto das irmãs... Mas sabe o J. C., lá? Ele virou, sabe?! Virou o disco. Ele mesmo que me tirou da vida dele, de perto dele. Ele falou assim pra mim que eu tô morrendo em pé no quintal que as irmãs não fazem nada pra mim. Que elas gostam de mim só pra cuidar de passarinho... Que ninguém aqui gosta de mim, ninguém aqui dentro gosta de mim... [...] De primeiro, a irmã me dava o pagamento dele pra entregar pra ele, nem assim ele não quis. Esse mês esperei, esperei, depois falei pra ela: "A senhora não vai me dar o pagamento do J., não, porque ele não quer. É pra senhora mesmo ir lá e entregar na mão dele”. É... Eu saia na rua com ele, de primeiro, eu ia nas Clínicas, na Santa Casa, 
acompanhava ele pra todo lado. Depois acabou, minha filha. Eu ajudava a comprar as coisas pra ele, comprar banana, porque ele não vem tomar lanche, só almoça e janta. Me preocupava com ele... É... Acabou... Ele não ia do quarto dele até na enfermaria, eu ia com ele lá. Eu cuidava dele, olhava ele... [silêncio] É... Eu era companheira dele pra isso, não pra outras coisas, pra sem-vergonhice, pra pouca-vergonha. Ele tem a mulher dele, tem os filhos dele. Ele também tocou a filha dele daqui, tocou a mulher. Tocou... É... [silêncio prolongado] Agora ele me humilha muito, pisa muito em mim, maltrata, me ofende... [...] A gente sente falta, né?! A gente sente falta sim. Tomava cerveja junto... Acabou... Agora tem que ficar assim mesmo, né?! Se conformar e pronto... [choro] As irmãs dele vêm aí chamar a gente pra ir lá. Na casa deles almoçar. Eles gostam de mim. A mulher dele mesmo gosta de mim... Não... [silêncio] Sabe aquele dia que choveu, que fez frio?! Eles não vieram. Já faz dois dias que eles falaram que vinham e não vieram. Vamos ver domingo agora, né, que o frio tá acabando. Se eles me chamarem eu vou... Domingo agora eu vou me arrumar, sentar e ficar esperando, né?! Se eles vierem, vieram, se não vierem...” [choro e silêncio prolongado]. (JÚLIA, 74 anos)

Esse relato ratifica a importância da relação interpessoal entre os idosos para a "sobrevivência" em instituições de longa permanência, sendo necessário considerar que a própria formação de vínculos na velhice é, potencialmente, um evento que predispõe seu rompimento e, conseqüentemente, a sua elaboração.

Segundo Silva et al. (2006), quando são estabelecidos vínculos afetivos entre pessoas idosas, elas sentem-se mais fortalecidos para enfrentar a tristeza. Sentimentos como dor, ansiedade e preocupação, são compartilhados entre eles. Na eminência de uma enfermidade de um amigo é percebida uma infinidade de sentimentos frente à possibilidade de perda deste companheiro.

\subsection{Outras perdas}

Mesmo sendo todas as fases do desenvolvimento humano experiências de morte em vida, a velhice é um momento de perdas freqüentes, em que o indivíduo tem que se despedir do trabalho, dos familiares, do seu corpo, seus pertences e, por fim, da própria vida. Perdas na funcionalidade - do trabalho - e da residência e pertences foram evidenciadas nos relatos de Flora e Júlia (que, inclusive, justificava a impossibilidade de voltar a morar com a família através do sentimento de incapacidade para trabalhar).

Eu tinha sete anos quando eu saí. Comecei a me virar, trabalhar, a ganhar meu dinheirinho... Até pouco tempo eu ainda tava trabalhando. [...] Trabalhei muito aqui 
também. Quando tinha o refeitório velho, eu era de uma turma que arrumava cozinha. Já trabalhei na capela, já trabalhei no porão, limpar o porão. Eu trabalhei treze anos com as irmãs... [...] Sinto falta do trabalho... Mas eu não sou mulher mais pra isso, não... De primeiro, eu limpava meu quarto. Meu quarto tá precisando limpar, dar uma vasculhada no teto, tá tudo cheio de teia de aranha. Hoje eu não dou conta mais, não... Chega de tarde eu fico doidinha pra deitar. Sete horas eu já tô dormindo... [...] Não queria [morar com a sobrinha]. Não posso trabalhar lá com ela, não posso ajudar ela em nada... (JÚLIA, 74 anos)

As perdas funcionais, de origem orgânica ou não, fazem parte dos lutos do envelhecimento, e são retratadas pela aposentadoria e seus desdobramentos, como a perda do poder econômico e da identidade profissional. Perdas relacionadas à atividades rentáveis e ao trabalho remunerado desencadeiam um processo de mudança e adequação de papéis um envelhecimento social -, o qual será dificultado na presença de um processo de luto complicado (BIRREN; SCHROOTS, 1984; BROMBERG et al., 1996).

Humm... Não [vontade de voltar para casa ao visitar o filho]... Só que eu abri tudo, guarda-roupa, tudo, olhava pras roupas... Cada vestido que eu subia no palco pra cantar! Eu cantava karaokê, né?! E olhar aquilo, dá uma saudade, né?! [silêncio e choro] No meu quarto, tinha tudo prateleira, né?! As roupas de cama, tudo dobrado... [silêncio] Fico com saudade e fico triste... [choro] Os vizinhos olhavam assim: “O, dona $R$.” Elas olhavam pra mim com uma cara de dó... Mas eu nunca falei nada, nunca contei nada... Mas elas percebiam alguma coisa, né?! "Vem aí um dia, almoçar junto com a gente", a vizinha. Eu falei: "Obrigado, quem sabe uma hora...". (FLORA, 81 anos)

Segundo Parkes (1998), uma pessoa não se identifica com uma casa do mesmo modo como se identifica com uma pessoa perdida, porém, o indivíduo pode realizar tentativas de reter, de alguma forma, o mundo que foi perdido. Parkes (1998) relata que estudos feitos no Centro de Estudos Comunitários da Escola de Medicina de Harvard, com indivíduos que passaram por experiências de realocação, mostraram dois padrões evidentes de processos de luto: excessivo e inibido, caracterizados, respectivamente, por reação exagerada e negação à perda da vizinhança da antiga residência.

Vê-se, portanto, que as circunstâncias da perda da residência podem ser um fator complicador do processo de luto, contudo, tanto uma preparação antecipatória como um apoio durante o período de transição podem ser úteis de maneira a permitir a elaboração de um quadro realista do novo mundo a ser construído, a fim de facilitar o trabalho de luto, com posterior aceitação da perda (PARKES, 1998). 


\section{CONSIDERAÇÕES FINAIS}

Pode-se considerar, portanto, que os idosos são primariamente seres humanos vivenciando a última fase do seu desenvolvimento - marcada inegavelmente mais por perdas que por ganhos. Com o asilamento, todas as perdas de uma vida tornam-se concretas, somadas com as perdas do próprio processo de institucionalização cujo luto deve ser elaborado a partir da sua chegada ao asilo.

Essa elaboração, já dificultada pela idade avançada e pela multiplicidade de perdas vividas, deve ser vista, a princípio, pelos cuidadores, como um objetivo a ser alcançado pelo idoso e que necessita, muitas vezes, de ajuda para fazê-lo. A atuação do cuidador como agente facilitador da elaboração do luto pelo idoso poderia minimizar a probabilidade de ocorrência do luto complicado e de suas consequiências, diminuindo, igualmente, a incidência de danos na saúde física.

O fato de escutar o idoso, simplesmente, e permitir que ele fale, que exponha suas idéias, que interaja, que sorria, é uma forma de ajuda que pode ser proporcionada, com pouco ou nenhum esforço, pelo cuidador. $\mathrm{O}$ idoso tem a necessidade de uma interação empática para que se sinta ativo, valorizado, vivo. É dessa interação que ele retira forças para que o asilo não se torne um mal necessário, e que o sinta, de fato, sua nova morada.

É sabido que a forma como o idoso enxerga sua vida exerce influência no modo como irá enfrentar o processo de envelhecimento. Se considera a vida satisfatória, será mais fácil aceitar as mudanças, físicas e psicológicas, de se tornar velho, sendo esse, outro aspecto a ser trabalhado pelos cuidadores asilares: a facilitação do enfrentamento da velhice pelo idoso de maneira saudável. Se o idoso vive intensamente o presente, "desliga-se mais" da morte.

Certamente, o achado mais importante nesse estudo, além da corroboração da multiplicidade de perdas presente na história de vida dos idosos institucionalizados, foi o sentimento de abandono inerente a todos esses idosos, tanto familiar quanto da sociedade em geral.

Quando o abandono familiar ocorre antes do asilamento, parece haver uma situação de conformação a respeito da condição de abandono, e a institucionalização é vista como conseqüência ao indivíduo que não tem família, emprego ou residência fixa, à medida em 
que este envelhece. No entanto, nos casos em que a separação familiar está diretamente relacionada com o asilamento - seja este como causa daquele, ou vice-versa - parece exercer uma influência muito maior na elaboração do luto pela institucionalização, dificultando-o.

Assim, o sentimento de abandono está certamente presente e é, na maioria das vezes, facilmente percebido em idosos institucionalizados, mesmo que o discurso inicial demonstrado por eles seja contrário a isso. Esse discurso é, muitas vezes, motivado por um mecanismo cultural. Em nossa sociedade, o pensamento que criou raízes é o de: "Deus me livre de depender dos meus filhos". Seria de se esperar que existisse um contrato social implícito no qual os pais cuidassem dos filhos durante a infância, e, na velhice, os papéis se invertessem. Porém, nota-se que, ao idoso, não agrada a idéia de ser um peso, uma carga, portanto, este mecanismo cultural não é suficiente para evitar a sensação de abandono promovida pela institucionalização.

Finalmente, é necessário considerar que é de responsabilidade dos cuidadores das instituições asilares a disponibilização de alguns recursos - como a facilitação da formação de vínculos, o auxílio à escuta e a empatia - para que sejam minimizados esses fatores potencialmente agravantes à saúde dos idosos institucionalizados. Assim, ao proporcionar subsídios para que sua permanência no asilo seja vista sob uma óptica positiva de viver a vida real, estará contribuindo para que sua vivência do asilamento não seja uma experiência desagradável. 


\section{REFERÊNCIAS BIBLIOGRÁFICAS}

AINSWORTH, M. D. S. Attachments beyond infancy. American Psychologist, v. 44, p. 709-716, 1989.

BARDIN, L. Análise de conteúdo. Tradução de Luís Antero Reto e Augusto Pinheiro. Lisboa: Edições 70, 1995.

BARREIRA, K. S.; VIEIRA, L. J. E. S. O olhar da enfermagem para o idoso: revisão de literatura. Rev. Enferm. UERJ, v. 12, p. 332-7, 2004.

BEAUVOIR, S. A velhice. Rio de Janeiro: Nova Fronteira, 1990.

BERTHOUD, C. M. E.; BROMBERG, M. H. P. F.; COELHO, M. R. M. Ensaios sobre formação e rompimento de vínculos afetivos. $2^{\mathrm{a}}$ ed. Taubaté: Cabral Editora Universitária, 1998.

BIRREN, J. E.; SCHROOTS, J. J. F. Steps to an ontogenetic psychology. Acad. Psychol. Bull., v. 6, p. 177-90, 1984.

BLEGER, J. Temas de psicologia - Entrevista e grupos. 2a . ed. São Paulo: Martins Fontes, 1998.

BOBBIO, N. O tempo da memória: de senectude e outros escritos autobiográficos. Rio de Janeiro: Campus, 1997.

BOWLBY, J. Separation: anxiety and anger. In: BOWLBY, J. Attachment and loss, v. 2. Harmondsworth: Penguin Books, 1978.

BOWLBY, J. Apego, perda e separação. São Paulo: Martins Fontes, 1985.

BOWLBY, J. Formação e rompimento dos laços afetivos. $2^{\text {a }}$. ed. São Paulo: Martins Fontes, 1990. (Psicologia e pedagogia)

BOWLBY, J. Apego e perda - perda: tristeza e depressão. São Paulo: Martins Fontes, 1993. (Psicologia e Pedagogia)

BRASIL. Ministério da Saúde/Gabinete do Ministro. Portaria 810, de 22-9-1989: aprova normas e padrões para funcionamento de Casas de Repouso, Clínicas Geriátricas e outras instituições destinadas ao atendimento de idosos, a serem observados em todo o território nacional. Diário Oficial da União; Poder Executivo, Brasília: 27 set. 1989. Seção 1.

BRASIL. Ministério da Saúde. Lei Federal 8.842, de 4-1-1994: dispõe sobre a política nacional do idoso, cria o Conselho Nacional do Idoso e dá outras providências. Diário Oficial da União; Poder Executivo, Brasília: 5 jan. 1994. Seção 1. 
BRASIL. Ministério da Previdência e Assistência Social/Secretaria de Assistência Social. Decreto Federal 1.948 de 3-7-1996: regulamenta a Lei n. 8.842, de 4-1-1994, que dispõe sobre a Política Nacional do Idoso, e dá outras providências. Diário Oficial da União; Poder Executivo, Brasília: 4 jul. 1996. Seção 1.

BRASIL. Ministério da Saúde/Gabinete do Ministro. Portaria 1.395, de 10-12-1999: aprovar a Política Nacional de Saúde do Idoso. Diário Oficial da União; Poder Executivo, Brasília: 13 dez. 1999. Seção 1.

BRASIL. Ministério da Saúde. Lei Federal 10.741, de 1-10-2003: Dispõe sobre o Estatuto do Idoso e dá outras providências. Diário Oficial da União; Poder Executivo, Brasília: out 2003; n.192. Seção 1.

BRITO, F. C.; RAMOS, L. R. Serviços de atenção à saúde do idoso. In: PAPALEO, M. Netto. Gerontologia. São Paulo: Atheneu, 1996.

BRITTEN, N. Qualitative research: qualitative interviews in medical research. BMJ, v. 311, n. 6999, p. 251-3, 1995.

BRITTEN, N. et al. Qualitative research methods in general practice and primary care. Fam. Pract., v. 12, n. 1, p. 104-14, 1995.

BROMBERG, M. H. P. F. A psicoterapia em situações de perdas e luto. São Paulo: Livro Pleno, 2000.

BROMBERG, M. H. P. F. ; KOVÁCS, M.J. ; CARVALHO, M.M.M.J. ; CARVALHO, V.A. Vida e morte: laços da existência. São Paulo: Casa do Psicólogo, 1996.

BROWN, G. W.; HARRIS, T. Social origins of depression: a study of psychiatric disorder in women. Londres: Tavistock, 1978.

BURATI, G. A assistência do idoso no Lar Padre Euclides de Ribeirão Preto/SP nas décadas de 1910 a 1950. 2002. 181f. Dissertação (Mestrado) - Faculdade de Filosofia, Ciências e Letras de Ribeirão Preto, Universidade de São Paulo, Ribeirão Preto, 2002.

CARUSO, I. A separação dos amantes. São Paulo: Diadorim Cortez, 1982.

CHAIMOWICZ, F. Os idosos brasileiros do século XXI: demografia, saúde e sociedade. Belo Horizonte: Postgraduate, 1998.

CHAIMOWICZ, F.; GRECO, D. B. Dinâmica da institucionalização de idosos em Belo Horizonte, Brasil. Rev. Saúde Pública, v. 33, n. 5, p. 454-60, 1999.

CLAYTON, P. J.; HALIKAS, J. A.; MAURICE, W. L. The depression of widowhood. $B r$. J. Psychiatr., v. 120, p. 71-8, 1972. 
CLEGG, F. Grief and loss in elderly people in a psychiatric setting. In: CHIGIER, E. (Ed). Grief and mourning in contemporary society, v. 1. London: Freund, 1988.

DAVIM, R. M. B.; TORRES, G. V.; DANTAS, S. M. M.; LIMA, V. M. Estudo com idosos de instituições asilares no município de Natal/RN: características socioeconômicas e de saúde. Rev. Latino-am. Enfermagem, v. 12, n. 3, p. 518-24, maio-junho 2004.

DENZIN, N. K.; LINCOLN, Y. S. (Ed). Handbook of qualitative research. Thousand Oaks: Sage, 1994.

DURAN, A.; TURNER, C. W.; LUND, D. A. Social support, perceived stress and depression following the death of a spouse in later life. In: LUND, D. A. (Ed.). Older bereaved spouses: research with practical applications. Nova Iorque: Hemisphere, 1989. p. 69-78.

FERREIRA, A. B. H. Dicionário Aurélio básico da língua portuguesa. São Paulo: Nova Fronteira, 1988.

GASS, K. A. Appraisal, copying and resources: markers associated with the health of widows and widowers. In: LUND, D. A. (Ed.). Older bereaved spouses: research with practical applications. Nova Iorque: Hemisphere, 1989.

GAZALLE, F. K.; LIMA, M. S.; TAVARES, B. F.; HALLAL, P. C. Sintomas depressivos e fatores associados em população idosa no Sul do Brasil. Rev. Saúde Pública, v. 38, n. 3, p. 365-71, 2004.

HAGUETTE, T. M. F. Metodologias qualitativas na sociologia. Petrópolis: Vozes, 1995.

HAIG, R. A. The anatomy of grief: biopsychosocial and therapeutic perspectives. Springfield, IL: Charles C. Thomas Publisher, 1990.

GREENHALGH, T.; TAYLOR, R. Papers that go beyond numbers (Qualitative research). $B M J$, v. 315, n. 7110, p. 740-3, 1997.

IBGE. Instituto Brasileiro de Geografia e Estatística. Censo demográfico de 2000. Rio de Janeiro, IBGE: 2000.

KALACHE, A.; VERAS, R. P.; RAMOS, L. R. O envelhecimento da população mundial: um desafio novo. Rev. Saúde Pública, v. 21, n. 3, p. 200-10, junho 1987.

KALISH, R. A. Death, grief, and caring relationships. Monterey, CA: Brooks/Cole Publishing, 1981.

KINSELLA, K. Population ageing in developing countries. In: CALLEJA J, (Ed.). Meeting the challenges of ageing populations in the developing world. Proceedings of an experts' group meeting. Malta: International Institute of Aging, 1996. p. 23-46. 
KOVÁCS, M. J. (Coord.). Morte e desenvolvimento humano. São Paulo: Casa do Psicólogo, 1992.

LALIVE D'EPINAY, C. J.; CAVALLI, S.; SPINI, D. The death of a loved one: impact on health and relationships in very old age. OMEGA, v. 47, n. 3, p. 265-84, 2003.

LÜDKE, M.; ANDRÉ, MEDA. Pesquisa em educação: abordagens qualitativas. São Paulo: EPU, 1986. (Coleção Temas Básicos de Educação e Ensino).

LUFT, L. Perdas \& ganhos. 30 ed. Rio de Janeiro: Record, 2005.

LUND, D. A.; CASERTA, M. S.; DIMOND, M. F. Impact of spousal bereavement on the subjective well-being of older adults. In: LUND, D. A. (Ed). Older bereaved spouses: research with practical applications. New York: Hemisphere, 1989.

MACHADO, C. C. Projeções multirregionais da população: o caso brasileiro (1980-2020) 1993. Dissertação (Mestrado) - Universidade Federal de Minas Gerais, Belo Horizonte, 1993.

MALKINSON, R.; BAR-TUR, L. Long term bereavement processes of older parents: the three phases of grief. OMEGA, v. 50, n. 2, p. 103-29, 2004-2005.

MARTINS, C. R. M. O envelhecer segundo adolescentes, adultos e idosos usuários do SESC Maringá: um estudo de representações sociais. 2002. 168 f. Dissertação (Mestrado em Psicologia) - Departamento de Psicologia, Universidade Federal de Santa Catarina, Florianópolis, 2002.

MAY, C. More semi than structured? Some problems with qualitative research methods. Nurse Educ. Today, v. 16, p. 189-91, 1996.

MINAYO, M. C. S. O desafio do conhecimento: metodologia de pesquisa social (qualitativa) em saúde. 1989. Tese (Doutorado em Saúde Pública) - Escola Nacional de Saúde Pública. Fiocruz, Rio de Janeiro, 1989.

MOTTA, A. B. Chegando pra idade. In: BARROS, M. M. L. (Org.). Velhice ou terceira idade. Rio de Janeiro: Fundação Getúlio Vargas, 1998.

MUCCHIELlI, R. A entrevista não-diretiva. Tradução de Sílvia Magaldi. 2a. ed. São Paulo: Martins Fontes, 1994. (Coleção Formação Permanente em Ciências Humanas).

NERI, A. L. (Org.). Desenvolvimento e envelhecimento: perspectivas biológicas, psicológicas e sociológicas. Campinas: Papirus, 2001a. (Coleção Vivaidade)

NERI, A. L. (Org.). Maturidade e velhice: trajetórias individuais e socioculturais. Campinas: Papirus, 2001b. (Coleção Vivaidade) 
ONU. Organização das Nações Unidas. Assembléia Mundial sobre envelhecimento: resolução 39/125. Viena, 1982.

PARKES, C. M. Psychiatric problems following the death of a parent in adult life. Bereavement Care, v. 14, n. 3, p. 26-8, 1995.

PARKES, C. M. Luto: ensaios sobre a perda na vida adulta. Tradução Maria Helena Pereira Franco. São Paulo: Summus, 1998. (Coleção Novas Buscas em Psicoterapia, v. 56)

PEREIRA, L. S. M. et al. Programa Melhoria da Qualidade de Vida dos Idosos Institucionalizados. In: ENCONTRO DE EXTENSÃO DA UFMG, 8. Anais... Belo Horizonte, 2005.

PINCUS, L. A família e a morte: como enfrentar o luto. Rio de Janeiro: Paz e Terra, 1989.

POPE, C.; MAYS, N. Qualitative research: reaching the parts other methods can not reach: an introduction to qualitative methods in health and health services research. $B M J$, v. 311, n. 6996, p. 42-5, 1995.

RICHARDS, J. G.; McCALLUM, J. Bereavement in the elderly. N. Z. Med. J., v. 89, p. 210-4, 1979.

ROOS, N. P.; HAVENS, B. Predictors of successful aging: a twelve-year study of Manitoba elderly. Am. J. Public Health, v. 81, p. 63-8, 1991.

ROSENBLOOM, C. A. The effects of bereavement on eating behaviors and nutrient intake in elderly widowed persons. J. Gerontol., v. 48, n. 4, p. 223-9, 1993.

SABLE, P. Attachment, anxiety, and lost of a husband. Am. J. Orthopsychiatry, v. 59, p. 550-6, 1989.

SANTOS, SSC. Gerontologia e os pressupostos de Edgar Morin. Textos Envelhecimento, v. 6, n. 2, 2003.

SILVA C. A., MENEZES M. R., SANTOS A. C. P. O., CARVALHO L. S., BARREIROS E. X. Relacionamento de amizade na instituição asilar. Rev Gaúcha Enferm, v. 27, n. 2, p. 274-83, jun 2006.

SILVA, C. A.; CARVAlHO, L. S.; SANTOS, A. C. P. O.; MENEZES, M. R. Vivendo após a morte de amigos: história oral de idosos. Texto \& Contexto Enferm, v. 16, n. 1, p 97104, janeiro-março 2007.

SILVA, Y. A. A enfermagem nos serviços e programas públicos de atenção ao idoso. Texto \& Contexto Enferm, v. 6, n. 2, p. 127-36, maio-agosto 1997. 
TEIXEIRA, M. B. Empoderamento de idosos em grupos direcionados à promoção da saúde. 2002. 105 f. Dissertação (Mestrado) - Fundação Oswaldo Cruz, Escola Nacional de Saúde Pública, Rio de Janeiro, 2002.

TRIVIÑOS, A. N. S. Introdução à pesquisa em ciências sociais: a pesquisa qualitativa em educação. São Paulo: Atlas, 1994.

TURATO, E. R. Tratado da metodologia da pesquisa clínico-qualitativa: construção teórico-epistemológica, discussão comparada e aplicação nas áreas de saúde e humanas. $2^{\mathrm{a}}$ ed. Petrópolis: Vozes, 2003.

VIEIRA, E. B. Manual de gerontologia: um guia teórico-prático para profissionais cuidadores e familiares. Rio de Janeiro: Revinter, 1996.

WASKOVIC, T. D.; CHARTIER, B. M. Attachment and the experience of grief following the loss of a spouse. OMEGA, v. 47, n. 1, p. 77-91, 2003.

WEISS, R. S. Marital separation. New York: Basic Books, 1975.

YAMAMOTO, A.; DIOGO, M. J. D. Os idosos e as instituições asilares do município de Campinas. Rev. Latino-am. Enfermagem, v. 10, n. 5, p. 660-6, setembro-outubro 2002. 
ANEXO A - PARECER DE APROVAÇÃO NO CEP/EERP/USP 


\section{APÊNDICE A - TERMO DE CONSENTIMENTO LIVRE E ESCLARECIDO}

Caro(a) senhor(a)

Estou convidando o(a) senhor(a) para participar de uma pesquisa que propõe investigar situações de perda e luto em idosos que vivem em asilos. Caso aceite, o(a) senhor(a) participará de uma conversa comigo, que será gravada em fita cassete, se o(a) senhor(a) permitir, e somente será utilizada em publicações científicas, porém, seu nome e dados pessoais não serão conhecidos por mais ninguém além de mim. $\mathrm{O}$ (a) senhor(a) não terá nenhum gasto, poderá pedir mais explicações quando quiser e poderá desistir de participar da pesquisa a qualquer hora, sem problema algum. Se estiver de acordo, peço que assine esta autorização. Muito obrigada pela sua participação.

Enfa. Dayana Ferrari Haddad

Assinatura do entrevistado

Pesquisadora responsável

Contato:

R. Dom Luiz do Amaral Mousinho, 1662 Apto 02

Jd. Paulistano Ribeirão Preto-SP CEP 14090-280

Tels: (16)3967-0613, (16)3961-4413 ou (16)9141-4852 


\section{APÊNDICE B - ROTEIRO DA ENTREVISTA}

Data:

Duração:

Nome:

Data de nascimento: Naturalidade:

Sexo: Profissão: Estado civil:

Tempo de residência na instituição:

Já residiu em outra instituição? ( )Não ( )Sim. Por quanto tempo?

Fale-me sobre o(a) senhor(a).

- Perdas;

- Separações;

- Lutos;

- Vinda ao asilo.

Dados de observação e auto-observação do pesquisador:

- Comportamento global;

- Apresentação;

- Expressões faciais;

- Entonação da fala;

- Gesticulações;

- Riso;

- Choro. 